\title{
Modern Soil Phytolith Assemblages used as Proxies for Paleoscape Reconstruction on the South Coast of South Africa
}

Irene Esteban ${ }^{1}$, Jan C. De Vynck ${ }^{2}$, Elzanne Singels ${ }^{3}$, Jan Vlok ${ }^{2}$, Curtis W. Marean ${ }^{4,5}$, Richard M. Cowling $^{2}$, Erich C. Fisher ${ }^{4}$, Dan Cabanes ${ }^{1,6}$, Rosa M. Albert ${ }^{1,7}, *$

1. ERAAUB. Dept. de Prehistòria, Història Antiga i Arqueologia. Universitat de Barcelona. Montalegre, 6, 08001 Barcelona (Spain).

2. Centre for Coastal Paleosciences, Nelson Mandela Metropolitan University, P.O. Box 77000, Port Elizabeth, 6031, South Africa

3. Dept. of Archaeology, Beattie Building, University of Cape Town, University Avenue, Cape Town, South Africa

4. Institute of Human Origins, School of Human Evolution and Social Change, PO Box 872402, Arizona State University, Tempe, AZ 85287-2402, USA

5. Faculty of Science, Nelson Mandela Metropolitan University, Port Elizabeth, Eastern Cape 6031, South Africa

6. Plant Foods in Hominin Dietary Ecology Research Group, Max Planck Institute for Evolutionary Anthropology, Deutscher Platz 6, 04103 Leipzig, Germany"

7. Catalan Institution for Research and Advanced Studies (ICREA)

* Corresponding author: R.M. Albert: rmalbert@ub.edu

\begin{abstract}
South Africa continues to receive substantial attention from scholars researching modern human origins. The importance of this region lies in the many caves and rock shelters containing well preserved evidence of human activity, cultural material complexity and a growing number of early modern human fossils dating to the Middle Stone Age (MSA). South Africa also hosts the world's smallest floral kingdom, now called the Greater Cape Floristic Region (GCFR), with high species richness and endemism. In paleoanthropological research, improving our capacity to reconstruct past climatic and environmental conditions can help us to shed light on survival strategies of hunter-gatherers. To do this, one must use actualistic studies of modern assemblages from extant habitats to develop analogies for the past and improve paleoenvironmental reconstructions. Here, we present a phytolith study of modern surface soil samples from different GCFR vegetation types of the south coast of South Africa. In this study, the phytolith concentration and morphological distribution are related to the physicochemical properties of soils, the environmental conditions and the characterization of the vegetation for the different study areas. Our results show that phytolith concentration relates mostly to vegetation types and
\end{abstract}


the dominant vegetation rather than to the type of soils. More abundant phytoliths from Restionaceae and woody/shrubby vegetation are also noted from fynbos vegetation and grass phytoliths are a recurrent component in all the vegetation types in spite of being a minor component in the modern vegetation. The grass silica short cells from these plants, however, suggest a mix of $\mathrm{C}_{3}$ and $\mathrm{C}_{4}$ grasses in most of the vegetation types with a major presence of the rondels ascribed to $\mathrm{C}_{3}$ grasses. The exceptions are riparian, coastal thicket and coastal forest vegetation, which are characterized by the dominance of $\mathrm{C}_{4}$ grass phytoliths.

\section{Introduction}

Recent studies on hominin evolution have emphasized the use and effectiveness of phytoliths for paleoenvironmental reconstructions (e.g. Barboni et al., 1999, 2007, 2010; Albert and Bamford, 2012; Albert et al., 2006, 2009, 2015; Bamford et al., 2006, 2008; Neumann et al., 2009; Mercader et al., 2009; Novello et al., 2015; Rossouw, 2009; Cordova and Scott, 2010; Cordova, 2013). These studies are often paired with actualistic studies of extant habitats, which can be used to develop analogies to help reconstruct past environments. Phytoliths - the silica microremains formed in living plant tissues - reproduce via the intra- and extra-cellular structures of certain plants, and their composition makes them extremely durable and able to be preserved in ancient soils and sediments for up to millions of years (Strömberg, 2002, 2004; Strömberg et al., 2007; Strömberg and McInerney, 2011; Dunn et al., 2015). Phytolith studies of palms, sedges, and woody eudicots are commonplace in Africa, but most phytolith studies of African paleoenvironments have focused on the grass family since it exhibits a variety of different shapes that have been linked to differences in paleovegetation. Commonalities between phytolith studies allows them to be subdivided into three broad types of research: 1) studies of modern plants that are aimed at identifying diagnostic morphotypes, which can later be used for the identification of botanical remains in fossil records (e.g. Runge, 1996, 1999; Runge and Runge, 1997; Albert and Weiner, 2001; Albert et al., 2009; Bamford et al., 2006; Fahmy, 2008; Mercader et al., 2009; Rossouw, 2009; Cordova and Scott, 2010; Eichhorn et al., 2010; Mercader et al., 2010; Radomski and Neumann, 2011; Cordova, 2013; Novello and Barboni, 2015); 2) studies of modern soils that investigate the limitations of phytoliths for reconstructing vegetation and climatic conditions (e.g. Albert et al., 2006, 2015; Bremond et al., 2005a, 2005b, 2008; Barboni et al., 2007; Barboni and Bremond, 2009; Mercader et al., 2011; Novello et al., 2012; Cordova, 2013; Garnier et al., 2013); and 3) combined studies of modern plants and modern soils for understanding deposition processes of phytoliths and postdepositional effects that may affect their preservation under different mineralogical and climatic conditions (Albert et al., 2006).

Fossil and genetic records indicate that the modern human lineage evolved in sub-Saharan Africa during the Middle Pleistocene, approximately 200,000 years ago (Clark et al., 2003; White et al., 2003; McDougall et al., 2005; Smith et al., 2007; Fagundes et al., 2007; Gonder et al., 2007; Behar et al., 2008). Based on recent genetic studies, the progenitor populations of modern humans may have been located in southern Africa (e.g. Schlebusch et al., 2012, 2013), and detailed records from numerous South African archaeological sites shows the subsequent cultural and behavioral evolution characteristic of modern humans, underscoring the importance of this 
region in our understanding of modern human origins (e.g. Brown et al, 2009, 2012; d'Errico et al., 2005; d'Errico and Henshilwood, 2007; Henshilwood et al., 2001, 2002, 2004; Jerardino and Marean, 2010; Texier et al., 2010; Watts, 1999, 2002; Marean et al., 2014). The south coast of South Africa is also located in the hyper-diverse Greater Cape Floristic Region (GCFR), which contains a high variety of edible plants (fruits, geophytes, etc.) (De Vynck et al., 2015) and a rich marine ecosystem (Menge and Branch, 2001; de Vynck et al. 2015) that may have supported human populations throughout the Pleistocene (Marean, 2010, 2011). Phytolith studies have already contributed to our understanding of modern human evolution in the GCFR (Albert and Marean 2012), but much remains to be resolved about the plant resources that Pleistocene huntergatherers used for food, fuel, and other activities and the environmental and climatic conditions present then.

\section{Background to the Research Region}

The GCFR comprises the world's most diverse extratropical flora, both in terms of richness and endemism (Colville et al., 2014), and it is comprised of five floristically and structurally-defined biomes that are distributed based on rainfall amount and type, soil conditions, and the underlying geological substrate. Listed in terms of the area of spatial extent, these biomes are: Fynbos, Renosterveld, Succulent Karoo, Thicket, and Forest. Our study area is located along the southern coast of the GCFR (Fig. 1) in a centralized area that receives rain from both the winter-driven circumpolar westerly systems and post-frontal events that are caused by moist air, which is advected across the warm Indian Ocean to produce rain at any time of the year (Deacon et al., 1992; Engelbrecht et al., 2014). The annual rainfall for the study area varies from 398 - $510 \mathrm{~mm}$ [supplied by South African Weather Service (Linnow, 2012 n.p)] with the driest and warmest periods occurring in late summer. The area generally has a moderate climate with an annual mean temperature of around $18{ }^{\circ} \mathrm{C}$, minimum average of $6^{\circ} \mathrm{C}$ and maximum average temperature not higher than $30^{\circ} \mathrm{C}$. Frost occurs rarely.

The study area is underlain by the Palaeozoic deposits of the Cape Supergroup that are characterized by Table Mountain Group sandstones (associated with mountains and ridges and coastal cliffs of the Cape Folded Belt) and Bokkeveld shales (associated with coastal forelands). In the eastern part of the study area the Palaeozoic sediments dip in an east-west fault and are filled by the Cretaceous Enon Formation comprising conglomerates and mudstones (Rogers, 1984; Malan, 1987). Much of the southern coastal plain is underlain by Pliocene limestone of the Bredasdorp Formation, which has been covered by alkaline Pliocene-Pleistocene sands of marine origin near the coastal margin. Inland of these sands are found patches of older aeolian sands that are leached and acidic (Rebelo et al., 1991). In comparison, shale and mudstone-derived soils are moderately fertile, yet those associated with leached sands are infertile. The calcareous sands associated with limestone, calcrete and coastal dunes are also relatively infertile due to their high alkalinity and subsequent low levels of plant-available phosphorous (Thwaites and Cowling, 1988).

The vegetation of the region has been mapped at 1:30,000 scale by Vlok and De Villiers (2007) and we used this assessment for identifying vegetation units within our study area. Four 
biomes are represented within the study area: Fynbos, Renosterveld, Thicket, and Forest (Berg et al., 2014). Fynbos is characterized as sclerophyllous, fire-prone shrubland, which is associated with acidic, infertile sands, and having a graminoid component that is dominated by Restionaceae. Renosterveld is a fire-prone shrubland found on shales and mudstones where the graminoid component is dominated by a mixture of $\mathrm{C}_{4}$ and $\mathrm{C}_{3}$ Poaceae. Thicket is a dense shrubland dominated by large and leathery-leaved shrubs and low trees that is associated with areas that are fire-protected (deep valleys and the coastal margin) and located on clay-rich soils and alkaline sands along the coast. Graminoids only comprise a few shade-tolerant grasses within the thicket. Lastly, Forests are characterized by a dense cover of evergreen trees that are associated with fire-free enclaves located in the foothills of the Folded Belt. Graminoids within these forests comprise shade tolerant Poaceae and Cyperaceae.

There is also a long and detailed record of human occupation in the study area. Blombos cave, located near Still Bay (Western Cape Province), preserves a detailed record of novel modern human behaviors dating during the Late Pleistocene, approximately 70-100 ka, which includes early evidence for bone tools, marine shell beads, pigment processing, and geometric artwork (Henshilwood and van Niekerk, 2014 and references therein). Near Mossel Bay, the Pinnacle Point Archaeological Complex (PPAC) consists of a series of caves and rock shelters that formed in excess of 1 million years ago (Marean et al., 2007). Preserved archaeological deposits in several of these sites shows distinctive behavioral complexity that includes early evidence for marine resource exploitation (Marean et al., 2007; Jerardino and Marean, 2010); use of pigment (Marean et al., 2007; Watts, 2010); heat-treatment of lithic raw materials (Brown et al., 2009); and the production of microlith-tipped projectile weapons (Brown et al., 2012). Within the immediate area of Pinnacle Point are several vegetation types with different taxonomic and functional assemblages that would have been accessible within the daily foraging range for a hunter-gatherer $(\sim 10 \mathrm{~km})$. This highly diverse flora would extend the foraging opportunities for modern humans occupying the Pinnacle Point area (Marean et al., 2014).

Studies of $\delta 18 \mathrm{O}$ and $\delta 13 \mathrm{C}$ isotope records in speleothems, have provided high resolution records of climatic and environmental changes at PP dating from the late Middle Pleistocene to the Late Holocene. The speleothem record from Crevice Cave documents a strongly $\mathrm{C}_{3}$ plant flora from $\sim 90-74 \mathrm{ka}$, and then an increase in $\mathrm{C}_{4}$ plants during the cooler MIS4, which is coincident with a shift in $\delta 18 \mathrm{O}$ that is interpreted to suggest increasing amounts of summer rain (Bar-Matthews et al., 2010).

Diverse and detailed paleoenvironmental records have also been derived from the analysis of large mammal and micromammal fauna, charcoal, phytoliths and pollen from archaeological and paleoanthropological sites at Pinnacle Point. Changes in micromammal taxa from deposits dating to MIS 6 and MIS5e-a at cave PP9C indicated climatic shifts, from colder conditions and more open grassy environment to warmer and wetter conditions and dense vegetation (Matthews et al., 2011). The phytolith study from PP13B cave showed a low grass representation during the earlier occupations, from $\sim 160$ to $\sim 120 \mathrm{ka}$, which was inferred to indicate the presence of Fynbos that naturally has a low grass component (Albert and Marean, 2012). The presence of Grass Silica 
Short Cell phytoliths (GSSCs - characteristic of $\mathrm{C}_{4}$ grasses) during MIS5c (Shelly Brown Sand) was interpreted as being indicative of at least some summer rain (Albert and Marean, 2012).

This study aims to assess the potential for using phytolith studies from modern surface soil samples to characterize the vegetation of the study area of the GCFR so as to better identify past environments and climate changes on the south coast of South Africa. The ultimate goal of this study is the identification of phytolith morphotypes and phytolith assemblages with the potential to be used as proxies for the paleoenvironment, paleoclimate and paleovegetation reconstructions at Pinnacle Point and other south coast sites. The present study builds on, and differs from, previous studies in South Africa that have been carried out by Cordova (2013) and Cordova and Scott (2010) based on three aspects: i) our study focuses specifically on the south coast; ii) our study incorporates the whole phytolith assemblage that is preserved in modern soils, including eudicotyledoneous plants (here after 'eudicots') and graminoids; and iii) our study accounts for the taphonomic processes that might have affected phytolith preservation and thus their representation in the phytolith record.

\section{Materials and Methods}

\subsection{Materials}

Fieldwork was undertaken over four field seasons (2006-2011) on the south coast of South Africa (Fig. 1). A total of seventy-two modern soil samples were collected during June (2006 and 2009), November (2010) and from August to October (2011) from twelve vegetation types corresponding to the general 5 biomes, namely limestone fynbos, sand fynbos, mountain fynbos, grassy fynbos (Fynbos biome), renosterveld (Renosterveld biome), strandveld, dune cordon, subtropical thicket, coastal thicket (Thicket biome), coastal forest (Forest Biome), riparian and wetlands (both azonal) (Table 1). Soils were collected beneath intact (not impacted by humanmanaged activities) vegetation at 5 to $10 \mathrm{~cm}$ depth in the different vegetation types in proportion to their relative extents in the study area. The study area has not experienced any tectonic activity or significant climate shifts over the past few thousand years (Marean et al., 2014) thus the phytolith assemblages in the topsoil should be representative of the modern vegetation. Since renosterveld in the southern Cape has been extensively transformed for agriculture most samples were from slopes too steep for cultivation (Kemper et al., 2000). Several related aspects that might have influenced the configuration of phytolith assemblages and their concentration and preservation in modern soils have also been taken into account, including: vegetation type, dominant plant species, soil texture, and soil $\mathrm{pH}$ (Table 1).

The preliminary phytolith results of modern soils from the area showed the presence of some morphotypes, similar to those described by Cordova and Scott (2010) and Cordova (2013) as papillated and no-papillated rondels and which these authors describe as being characteristic of Restionaceae. In order to clarify whether our morphotypes corresponded to this family we present here the first results of the analyses of four Restionaceae plant specimens collected in the study area (Elegia juncea, Thamnochortus insignis and T. rigidus and Restio triticeus) (Table A1).

\subsection{Methods}




\subsubsection{Physico-chemical analyses}

The physico-chemical analyses (soil texture and $\mathrm{pH}$ ) of the 2011 samples were carried out at Bemlab laboratories in Cape Town, South Africa. The $\mathrm{pH}$ analysis of the samples from 2006, 2009, and 2010 was carried out using a CRISON BASIC 20+ pH-meter and texture was analyzed using Fourier Transformed Infrared Spectroscopy (FTIR), all at the Laboratory of Archaeology of the University of Barcelona. Infrared spectra were obtained using $\mathrm{KBr}$ pellets (potassium bromide) at $4 \mathrm{~cm}^{-}{ }^{1}$ resolution with a Nicolet iS5 spectrometer.

\subsubsection{Phytolith analysis}

The phytolith extraction from modern soils and Restionaceae plant specimens was carried out at the Laboratory of Archaeology of the University of Barcelona. Methods for the modern soils followed Katz et al. (2010). An initial sediment weight of between 30 and $50 \mathrm{mg}$ was required. Carbonate minerals were dissolved adding 50 microliters of hydrochloric acid $(6 \mathrm{~N} \mathrm{HCl})$. After the bubbling ceased, $450 \mathrm{ml}$ of $2.4 \mathrm{~g} / \mathrm{ml}$ sodium polytungstate solution $\mathrm{Na}_{6}\left(\mathrm{H}_{2} \mathrm{~W}_{12} \mathrm{O}_{40}\right) \mathrm{vH}_{2} \mathrm{O}$ ] was added. The tube was vortexed, sonicated and centrifuged for $5 \mathrm{~min}$ at $5000 \mathrm{rpm}$ (MiniSpin plus, Eppendorf). The supernatant was subsequently removed to a new $0.5 \mathrm{ml}$ centrifuge tube and vortexed. For examination under the optical microscope, an aliquot of $50 \mathrm{ml}$ of the supernatant was placed on a microscope slide and covered with a $24 \mathrm{~mm}$ x $24 \mathrm{~mm}$ cover-slip. Quantification of the total phytoliths was based on 20 fields at 200x magnification whereas morphological identification of phytoliths took place at 400x magnification. Minimally, 200 phytoliths were counted for the morphological analysis and when this was not possible we analyzed only those samples with a minimum number of 50 phytoliths in order to obtain as much information as possible (Albert and Weiner, 2001).

The phytolith extraction process from Restionaceae modern plants is a modification of the methods described in Albert and Weiner (2001) and Parr et al. (2001). Washed and air dried aliquots were weighed and burned in a muffle furnace at $500{ }^{\circ} \mathrm{C}$ for 2.5 hours. The ash was treated with an equivolume solution of $1 \mathrm{~N} \mathrm{HCl}$ for $30 \mathrm{~min}$ at $100{ }^{\circ} \mathrm{C}$, to leave only the siliceous minerals where phytoliths are found. The inorganic acid insoluble fraction (AIF) was centrifuged, re-suspended in deionized water, and centrifuged again. The supernatant was discarded and the washing was repeated three times. The pellet was transferred to a glass Petri dish and about $10 \mathrm{ml}$ of $30 \%$ hydrogen peroxide $\left(\mathrm{H}_{2} \mathrm{O}_{2}\right)$ was added. The sample was evaporated on a hot plate at $70^{\circ} \mathrm{C}$. More hydrogen peroxide was added as needed until all bubbling ceased. The remaining residue was carefully removed from the Petri dish, weighed, and transferred into an Eppendorf tube for storage. Microscope slides were prepared using around $1 \mathrm{mg}$ of the final fraction with Entellan mounting media (Merck). Phytolith counting and identification followed the procedures described above for the soil samples.

\subsubsection{Phytolith morphological identification and classification}

Morphological identification of phytoliths was based on our modern plant reference collection that has been compiled from plant species that are found in the study area (Esteban, unpublished data). The study also includes the four Restionaceae specimens described here. Reference 
collections from other study areas have also been consulted (Albert and Weiner, 2001; Bamford et al., 2006; Albert et al., in press). Additionally, the results were also compared to the modern reference collection of graminoids from South Africa developed by Rossouw (2009), Cordova and Scott (2010), and Cordova (2013). Standard literature (Mulholland and Rapp, 1992; Piperno, 1988, 2006; Twiss et al., 1969 and references therein) was also accessed when necessary. The terminology for describing phytolith morphotypes was based on the anatomical and/or taxonomic origin of the phytoliths. When this was not possible, geometrical traits were followed. The International Code for Phytolith Nomenclature (ICPN) was also followed where possible (Madella et al., 2005).

\subsubsection{Statistical analysis}

Statistical analysis one-way ANOVA and a post hoc Tukey Honest Significant Differences (HSD) tests were performed on the dataset in order to identify those morphotypes that are statistically representative of specific vegetation types or biomes. These tests account for the variation in total numbers of phytolith morphotypes counted for each vegetation type and biome. The null hypothesis in each test assumes that there is no significant difference in the distribution of phytolith morphotypes between the different vegetation types and biomes from the GCFR.

The non-parametric Kruskal Wallis test was also used to identify significant differences in the mean values of phytolith indices between vegetation types since data were non-normally distributed (Shapiro-Wilk test for normality).

All statistical procedures were performed with the JMP-SAS12.1.0 software. Samples from mountain fynbos, fynbos/renosterveld, dune cordon, coastal forest and wetlands were excluded from the statistical analysis due to the absence of replicated samples from the same vegetation type or because phytoliths were absent or identified in few concentrations as occurred for dune cordon vegetation. Only samples from riparian vegetation represent Azonal vegetation.

\section{Results}

Table 1 lists the results of the analysis of the sediment samples, which includes information about the samples, vegetation type, geographical coordinates, the dominant taxa, the type of soils and the $\mathrm{pH}$ of soils as well as the estimated phytolith concentration in sediments, the total number of phytoliths that were identified, the percentage of weathered morphotypes and the $\mathrm{D} / \mathrm{P}^{\mathrm{o}}, \mathrm{Fy}, \mathrm{Iph}$ and Ic indices values. Table 2 lists the distribution of phytolith morphotypes in the samples and their plant attribution (plant types and plant parts). These morphotypes were later related to the vegetation type, the dominant plants, and the type of soil. All of the samples showed an acidic to a moderate alkaline $\mathrm{pH}$. FTIR results further indicated that clay and quartz are the main mineral components in all the samples but these minerals occurred in different proportions depending on the type of soils.

Phytoliths were identified in different concentrations in all of the analyzed samples. Renosterveld, riparian vegetation, and grassy fynbos vegetation provided the highest amount of phytoliths per gram of sediment (g/sed) (Table 1). In contrast, the samples that were collected from limestone fynbos, dune cordon, coastal thicket and strandveld vegetation had the lowest 
amount of phytoliths. Weathered morphotypes showing irregular shapes and pitted surfaces were identified in low numbers in all the samples and almost never above $20 \%$, with the exception of samples from coastal thicket. Together with phytoliths, diatoms and sponge spicules were also recovered from most of the samples, albeit in varying amounts. Samples from riparian, subtropical and coastal thicket vegetation contained the highest number of diatoms.

Grass phytoliths were common to all vegetation types analyzed. Samples from limestone fynbos showed a low grass phytolith component (Table 2). Among grasses, GSSCs were the most representative morphotypes, together with the presence of prickles, bulliforms fan-shaped as well as long cell with decorated margins (mainly echinates) (Fig. 2a, b, and c, respectively). GSSCs have been used widely as climatic indicators due to their characteristic morphologies that generally relate to different Poaceae subfamilies. For example, rondels, which include trapezoids are common in $\mathrm{C}_{3}$ Pooideae, bilobates and crosses in $\mathrm{C}_{4}$ Panicoideae and saddles in $\mathrm{C}_{4}$ Chloridoideae (Twiss, et al., 1969; Twiss, 1987, 1992; Fredlund and Tieszen, 1994, 1997). In addition to Pooideae, GSSC rondels have also been identified in South Africa in the $\mathrm{C}_{3}$ Ehrhartoideae and Danthonioideae subfamilies (Cordova and Scott, 2010; Cordova, 2013). Finally, oblongs are common in $\mathrm{C}_{3}$ Pooideae grasses. Accordingly, GSSCs have been classified in four categories: rondels (rondels, trapezoids, towers), lobates (bilobates, crosses and polylobates), saddles and oblongs. Rondels were the most common GSSCs recognized in our samples (Fig. 2d, e and f), while lobates (Fig. 2g and h) and saddles (Fig. 2i) were also represented, albeit in lower numbers. The distribution of grasses in the phytolith record was traced using a ternary diagram highlighting composition differences among vegetation types and GSSCs (Fig. 3). Here the category rondels include also the oblong morphotypes. The latters dominate most of the vegetation types while samples from riparian vegetation present higher proportion of saddles (Fig. 3).

Among eudicot plants the most representative phytoliths were parallelepiped blockys, epidermal ground mass polyhedral (Fig. 2j), eudicot hair cells (Fig. 2k) and sclerenchyma (Fig. 21). Psilate and rugulate spheroids were also identified in high frequencies mainly in samples from limestone fynbos vegetation.

Other common morphotypes that were identified included large spheroids, sometimes showing protuberances, with granulate or verrucate decoration $(\sim 25 \mu \mathrm{m})$ (Fig. 4a-c) and spheroids showing spiraling decoration, sometimes showing a double ring on the edges $(10-15 \mu \mathrm{m})$ (Fig. $4 \mathrm{~d}-\mathrm{f})$. These morphotypes resemble those described by Cordova and Scott (2010) and Cordova (2013) as being representative of fynbos, strandveld, and dune cordon vegetation (both thicket-fynbos mosaics), and marginally renosterveld vegetation. Our comparison with the modern Restionaceae plants (Elegia juncea, T. insignis, T. rigidus and Restio triticeus) confirmed that these morphotypes correspond to Restionaceae plants (Fig. 4g-1). In this work we have chosen not to follow Cordova's (Cordova and Scott, 2010; Cordova, 2013) distinction between papillated and non-papillated rondels since they have, in fact, spheroidal shapes that can be recognized when rotating phytoliths under the microscope. Elongate phytolith morphotypes were also observed in Restionaceae plants. Because these are also produced by other plants they were not used here as representative of Restionaceae. Furthermore, psilate and rugulate spheroids $(\sim 10 \mu \mathrm{m})$ were also 
identified in our modern plants (Fig. 5 a-d), each having similar shapes, decorations, and sizes to the ones that were identified in the wood and bark of trees and shrubs (Fig. 5 e-h) from our modern plant reference collection in the study area (Esteban, unpublished data). In order to circumvent any confusion with psilate or rugulate spheroid phytoliths, which are both produced in Restionaceae (Fig. 5a-d) and eudicot wood (Fig. 5e-h) (Table A1), the characteristic large granulate spheroids and verrucate spheroids showing spiraling decoration from Restionaceae are both referred to here as restio phytoliths.

\section{Phytolith indices}

Phytolith indices have been used widely as indicators of aridity [Iph (\%) index] (Diester-Haass et al. 1973, Alexandre et al., 1997; Novello et al., 2012); climate conditions based on the $\mathrm{C}_{3}-\mathrm{C}_{4}$ grass distribution [Ic index] (Twiss, 1992; Barboni et al., 2007; Bremond et al., 2008); tree cover density [D/P ${ }^{\circ}$ index] (Alexandre et al., 1997-D/P index; Barboni et al., 1999; Bremond et al., 2005a; Bremond et al., 2008); evapotranspiration and water stress [Fs index] (Bremond et al., 2005b; Novello et al., 2012; Fisher et al., 2013); and aquatic and xerofitic grass dominance [Iaq and Ixe indices] (Novello et al., 2012, 2015). Here, we used the $\mathrm{D} / \mathrm{P}^{\mathrm{o}}$ index (Bremond et al., 2008) to identify shrubby vegetation/tree cover density, which is defined as follows:

$$
\frac{\text { psilate spheroids }+ \text { rugulate spheroids }}{\sum G S S C s}
$$

The Ic and Iph indices were also used to further characterize grass distribution among vegetation types. We modified the formula by eliminating the percentage, so they are defined as follows:

$$
\begin{gathered}
\text { Ic }=\frac{\text { GSSC Rondels (rondels, towers, trapezoids and oblongs) }}{\sum G S S C s} \\
\text { Iph }=\frac{G S S C \text { Saddles }}{\sum G S S C \text { S Saddles and Lobates }}
\end{gathered}
$$

Furthermore, we have defined a new phytolith index that is specific to the identification of fynbos vegetation, which we term the Fy index. Since fynbos is shrub-dominated vegetation with a high Restionaceae and a low grass component (Berg et al., 2014), we defined the Fy index as the ratio of restio phytoliths and spheroids psilate and rugulate phytoliths to the sum of GSSCs, which is defined as follows: 


\section{restio + psilate spheroids + rugulate spheroids phytoliths \\ $\sum$ GSSCS}

As we pointed out above, spheroids psilate and rugulate phytoliths were identified in the wood of trees and shrubs and in Restionaceae from our plant reference collection making it impossible to distinguish each phytolith morphotype from one-another. Considering that fynbos is a shrub-dominated vegetation and Restionaceae are the diagnostic family of the Fynbos biome, we have therefore assumed that the identification of spheroids psilate and rugulate, whether they are produced by woody eudicots or Restionaceae, are representative of fynbos vegetation. Thus the Fy index provides a signal for the presence of vegetation characteristic of the Fynbos biome. Furthermore, we assume that in samples from vegetation types devoid of Restionaceae plants, and also having no restio phytoliths, spheroid morphotypes might be representative of woody eudicots.

The Kruskal-Wallis test showed a statistically significant difference between the $\mathrm{D} / \mathrm{P}^{\mathrm{o}}$ and Fy index values by vegetation type $\left(\mathrm{x}^{2}=24.92, p=0.0008\right.$ and $\mathrm{x}^{2}=24.84, p=0.008, \mathrm{D} / \mathrm{P}^{\mathrm{o}}$ and Fy indices respectively) with the highest mean ranks for limestone fynbos (46.33 for both indices) and the lowest mean ranks for grassy fynbos (8.5 and 19.5, D/P and Fy indices respectively) and riparian vegetation (12.86 and 11.07, D/P and Fy indices respectively) (Fig. 6a and b). Iph values also detected statistically significant differences between vegetation types $\left(\mathrm{x}^{2}=16.84\right.$, $p=0.0184$ ) with the highest mean rank of 39.93 for riparian, 33.75 for coastal thicket and 32.5 subtropical thicket (Fig. 6c). There were no significant differences in the Ic index between vegetation types $\left(\mathrm{x}^{2}=12.81, p=0.0769\right)$. Nonetheless, samples from renosterveld had the largest numbers of GSSC rondels, while riparian and coastal thicket the lowest (Fig. 6d).

\section{Fynbos biome}

\section{Limestone fynbos}

The dominant vegetation of the sampled areas consisted mainly of restios, Asteraceae shrubs and other eudicot small trees and shrubs. Grasses were either absent or barely present (Table 1). The few grasses that were observed corresponded to either Ehrharta or Themeda.

Phytoliths from limestone fynbos vegetation were identified in low concentration ranging from 7,000 to 160,000 phytoliths $\mathrm{g} / \mathrm{sed}$. This low phytolith concentration might be related to the restio and Asteraceae dominance, which produce low amounts of phytoliths, combined with the low presence of grasses (Table 1). Interestingly, the only sample (LF11-23) where Themeda triandra $\left(\mathrm{C}_{4}\right.$ Panicoideae) was part of the dominant vegetation also showed low phytolith concentration.

Out of the seven samples analyzed from this vegetation type, three showed enough phytoliths for a reliable morphological interpretation (LF11-23, LF11-68 and LF11-85). Although grasses were not common in the vegetation type, grass phytoliths were well represented in the phytolith record. Rondel phytoliths were most common among GSSCs (mean: 51.3\%) whereas lobates were also less frequent (mean: 38.7\%). Interestingly, we observed that despite Themeda trianda was the dominant grass species from sample LF11-23 area, which produces GSSC bilobates in 
high numbers (Rossouw, 2009), it had the lowest counts of GSSC lobates. Consistent with the vegetation, restio phytoliths were identified in high frequencies in all the samples (Table 2). Hatshape phytoliths from the Cyperaceae family were identified in samples LF11-68 although sedges were not identified in the field. Eudicot phytoliths, mainly from wood and bark, were identified in high quantities in all the samples analyzed, where spheroid psilates were the most representative morphotypes (Table 2)

\section{Sand fynbos}

The vegetation present during sampling varied greatly in the different sampled areas. However, eudicots such as Leucadendron salignum, Leucospermum praecox and L. muirii, Protea repens, and some Erica spp. were highly represented. Restios were also well represented and grasses dominated in some of the areas (Table 1).

Out of the nine samples that we analyzed from sand fynbos, those from grass-dominated areas exhibited the highest phytolith concentration (SF11-42 and SF11-43). The samples having the lowest phytolith concentration corresponded to areas where eudicot plants dominated (SF10-05, SF10-06, SF11-37, SF11-47, SF11-62, SF11-82) (Table 1). The exception was sample SF11-45, which showed a high phytolith concentration and little grass-cover.

Overall, grass phytoliths dominated sand fynbos samples and among those grass phytoliths that were identified, GSSC rondels were the most representative morphotypes, accounting for 57\% (mean) of the different GSSCs (Table 2 and Fig. 3). Restio phytoliths were also identified in high frequencies. Interestingly, samples SF11-45 and SF11-47, which were collected from areas where restios did not dominate, showed the highest concentration of these morphotypes (Table 1 and 2). Cyperaceae hat-shape phytoliths were also identified in some sand fynbos samples, and these morphotypes were also observed in samples from limestone fynbos vegetation, even though they were not dominant in the vegetation (SF10-05, SF11-37, SF11-47 and SF11-62). Eudicot phytoliths (mainly spheroids from the wood/bark) were identified in all the samples in high numbers with the exception of samples SF11-42 and SF11-43.

\section{Grassy fynbos}

Grassy fynbos vegetation was dominated by grasses such as Themeda trianda $\left(\mathrm{C}_{4}\right.$ Panicoideae), Eragrostis capensis and E. curvula $\left(\mathrm{C}_{4}\right.$ Chloridoideae) and Pentachistis colorata $\left(\mathrm{C}_{3}\right.$ Danthonioideae) (Table 1). Phytolith results showed a high phytolith concentration with a dominance of grass characteristic phytoliths (mainly GSSCs and bulliform cells) (Table 2). Samples SF11-42 and 43 presented the highest grass content of all the samples. Among GSSCs, rondels are represented in high frequencies in the two samples (GF10-10 and GF10-11), where Pentachistis colorata, Themeda trianda and Eragrostis curvula and E. capensis were dominant (Fig. 3). Even though chloridoids dominated in sample GF10-10, GSSC saddles were identified

in low frequencies. Conversely, sample GF10-14, which was collected from a hilltop in the Brenton Lake area, contained high frequencies of GSSC lobates and saddles. Restios and eudicot phytoliths (leaves and wood and bark) were also identified although in very low frequencies (Table 2). These results are consistent with the low presence of these plants in this vegetation 
type.

\section{Mountain fynbos}

Only one sample was collected from mountain fynbos vegetation (MF12-01). The sample was collected from an area where restios and sedges dominated the plant cover, but there were some associated shrubs (Table 1). Phytoliths were identified in relatively high concentration and were dominated by rondel GSSCs (Table 2; Fig. 3). Restio phytoliths were not recorded in high numbers, although these plants dominated the vegetation at the collection area. Spheroids phytoliths were also identified in relatively high concentrations (Table 2).

\section{Renosterveld biome}

\section{Renosterveld}

Renosterveld vegetation on the Cape south coast (south of Langeberg and Riviersonderend Mountains) is considered to be a distinct vegetation type on account of the high abundance of largely C4 grasses and $50-70 \%$ plant cover (Mucina and Rutherford, 2006). The species composition of renosterveld differs significantly from any fynbos vegetation types due the lack of Proteaceae and Ericaceae species. The dominant vegetation in the 17 samples analyzed from renosterveld was composed of shrubs such as Elytropappus rhinocerotis (commonly known as renosterbos), other Asteraceae shrubs and various family grasses $\left(\mathrm{C}_{4}\right.$ Panicoideae and Chloridoideae, and $\mathrm{C}_{3}$ Ehrhartoideae and Danthonioideae) (Table 1).

Quantitatively most of the samples from renosterveld showed the highest phytolith concentration in comparison to other vegetation types, ranging from 4.8 to 1.2 million phytoliths $\mathrm{g} / \mathrm{sed}$. The only exceptions were samples RV11-15 and RV11-58, with much lower counts (Table 1). As with other vegetation types, samples containing the highest phytolith concentration were collected from areas where grasses were dominant.

All the samples showed similar phytolith assemblages with grasses dominating and restios and eudicot plants represented in lesser amounts (Table 2). GSSC rondels were the most abundant morphotypes identified among grasses. The exceptions were samples RV09-01, RV11-15 and RV11-58, which contained a higher presence of GSSC saddles and lobates, that each made up around $30 \%$. Sample RV09-01 was collected from an area where $\mathrm{C}_{4}$ grasses dominated, such as Themeda trianda and Brachiaria serrata $\left(\mathrm{C}_{4}\right.$-Panicoideae) and Eragrostis curvula and $E$. capensis $\left(\mathrm{C}_{4}-\right.$ Chloridoideae) along with Cymbopogon marginatus $\left(\mathrm{C}_{4}-\right.$ Andropogonae). Restio phytoliths were also identified but in very low frequencies (Table 2). Though restios were recognized in most of the sampled areas, they did not represent a dominant component. Among eudicots, spheroid phytoliths were in slightly higher frequencies with the exception of samples RV09-03 and RV11-67 despite vegetation growing in these plots being similar to the other ones. Nonetheless, we need to bear in mind that because grass phytoliths were identified in very high numbers both restio and woody plants, which are low phytolith producers, might appear underrepresented in the phytolith record.

\section{Transition fynbos/renosterveld}


One sample was collected from this area where vegetation showed characteristic elements from both fynbos and renosterveld vegetation that had high grass presence, restios, and shrubs (F/RV10-07). This sample was collected below Tritoniopsis sp. and Restionaceae. The phytolith concentration was similar to both grassy fynbos and renosterveld samples (Table 1). The phytolith assemblage was dominated by grasses although restios and eudicot phytoliths were also well represented. GSSC saddles dominated among other different GSSCs making up 50\% of the assemblage (Table 2). No further characterization of transition vegetation could be inferred through the phytolith assemblage.

\section{Thicket biome}

\section{Subtropical thicket}

Subtropical thicket vegetation was dominated by eudicot plants characterized mainly by Sideroxylon inerme, Eriocephalus africanus and Searsia pterota. Of the three samples analyzed from this vegetation type, only sample StT09-06 contained a high phytolith concentration (1.2 million phytoliths $\mathrm{g} / \mathrm{sed}$ ) (Table 1). The phytolith assemblage from this sample showed low morphological variety with a dominance of grasses even though wood/bark phytoliths were also well represented. Among the grasses, GSSCs rondels were the dominant morphotype and lobates and saddles were identified in much lower frequencies (Table 2).

\section{Coastal thicket}

Six samples were collected from the densely vegetated cliff area around Pinnacle Point where Euclea racemosa, Euphorbia spp., Sideroxylon inerme, Grewia occidentalis, Lycium sp., Zygophyllum morgsana and Cassine peragua dominated. Grasses were also present in some of the areas, and Eragrostis spp. dominated in sample CT06-05 (Table 1). Our results showed very low phytolith concentration overall, with the only exception being sample CT06-07 (900,000 phytoliths g/sed), which was collected from a loamy soil. Out of eight samples collected only four (CT06-01, CT06-02, CT06-05 and CT06-06) contained enough phytoliths for a reliable interpretation of their data. Furthermore, despite the diversity of eudicot plants in coastal thicket vegetation, our samples showed low morphological variety with characteristic grass phytoliths being the most abundant. Among these grasses, GSSC saddles dominated along with lobates morphotypes (Table 2). For example, in sample CT06-05, where Eragrostis spp. was the dominant plant component, GSSC saddles represented the $92 \%$. Whereas no palm species occur in the GCFR today, spheroid echinates, characteristics of the Arecaceae family, were identified in samples CT06-02 and CT06-05 although in low frequencies. Spheroids and characteristic eudicot leaf phytolith morphotypes were identified in low frequencies in spite of the denser woody vegetation occurring in the area (Table 2).

\section{Strandveld}

The dominant vegetation in our sampled areas was grasses (mainly $C_{3}$ Ehrhartoideae), restios, asteraceous plants and other trees or shrubs such as Stoebe cinorera, Sideroxylon inerme, Agathosma spp., Searsia spp. and Metalasia sp. (Table 1). 
Out of the seven samples that we analyzed, only three samples (STV11-1, STV11-16 and STV11-21) contained enough phytoliths for reliable interpretations. As with other vegetation types, the highest phytolith concentration corresponded to areas where grasses were dominant (Table 1). The phytolith assemblage recovered from these samples is most characteristic of fynbos vegetation, whereas grass phytoliths dominated in all the samples. Among GSSCs, rondels were dominant and associated with lobates and saddles in most of the samples (Table 2). This is consistent with Ehrhartoideae being the most representative grass family in the area. Restio phytoliths and spheroids were present in high frequencies in sample STV11-1.

\section{Dune cordon}

The vegetation present in dune cordon areas was characterized by asteraceous plants and other shrubby vegetation with few grassy elements (only Ehrharta villosa was identified). Dune cordon samples also had the lowest phytolith concentrations. No sample had phytolith concentration exceeding 100,000 phytoliths g/sed (Table 1) and only sample DC11-18 contained enough phytoliths for a reliable interpretation of the data. Furthermore, grass phytoliths dominated these samples even though grasses were rarely observed in the understorey of dune cordon vegetation (Table 1 and Table 2). Among grasses, GSSC rondels were the dominant morphotypes while saddles were also well-represented. Restio phytoliths were noted although in low numbers. Eudicot phytoliths, mainly spheroids from the wood and bark, were identified in relatively high frequencies in all the samples (Table 2).

\section{Forest biome}

\section{Coastal forest}

Coastal forest area was densely vegetated and dominated by eudicot trees such as Celtis sp. and Vepris sp., as well as other eudicot herbs and shrubs. The understorey was composed of grasses, although they were not part of the dominant vegetation. Our quantitative results showed relatively high phytolith concentration (345,000 phytolith g/sed) (Table 1). In relation to morphology, grasses dominated the phytolith assemblage making up 86\%. Contrary to other samples, GSSC lobates dominated here, making up 50\% of the total phytolith morphotypes identified. Few phytoliths characteristics of eudicot leaves as well as few parallelepiped blocky morphotypes probably from the wood and bark of eudicot were identified (Table 2).

\section{Azonal vegetation}

\section{Riparian}

The winter-deciduous Acacia karroo and other eudicot trees or tall shrubs, as well as several asteraceous plants, dominated in most of the sampled areas. Grasses were present as part of the dominant vegetation for most of the areas in association to other herbaceous plants (Table 1).

Together with grassy fynbos and renosterveld, samples from riparian vegetation contained the highest phytolith concentration, ranging from 4.3 million to 97,000 phytoliths g/sed. Samples with the highest phytolith concentration corresponded to areas dominated by grasses (Table 1). Morphologically, grass phytoliths were the major component with a minor presence of phytoliths 
from other plants (Table 2). GSSC saddles were the most representative morphotypes. Although restios were not present in the sampled areas, Restio phytoliths were identified in samples RP1148, RP11-59 and RP11-79. Hat-shape phytoliths, characteristic of the Cyperaceae family, were only identified in sample RP11-79, and in very small abundance ( 1\%). Eudicot phytoliths, both from wood/bark and leaves, were noted in low frequencies in all the samples (Table 2).

\section{Wetlands}

The wetlands in our study area are seasonally inundated sites that are adjacent to rivers and floodplains. Water levels may vary throughout the year, but the sites are inundated for at least several weeks per annum. Our sample was collected from the riverside of the Little Brak River where Cyperaceae and Arundo grasses dominated. Some eudicot trees and shrubs were also present. Phytoliths were identified in high numbers (1,590,000 phytolith $\mathrm{g} / \mathrm{sed})$ (Table 1). The phytolith assemblage was dominated by grass and wood/bark phytoliths. Despite $\mathrm{C}_{4}$ Panicoideae grasses dominated the vegetation, GSSC lobates were identified in low frequencies (Table 2). Characteristic sedge phytoliths (hat-shape) were absent from the phytolith assemblage.

\section{Statistical analysis}

The results from the ANOVA test showed statistically significant differences between nine out of the twenty-two phytolith morphotypes between vegetation types and in eight out of the twentytwo phytolith morphotypes between biomes $(\mathrm{p}<0.05)$ (Table A2 and A3, respectively). Subsequently, we ran those significant phytolith morphotypes through a post hoc Tukey's HSD test, which is represented in Figure 7 (phytolith morphotypes in regards to vegetation types) and Figure 8 (phytolith morphotypes in regards to vegetation biomes). These results indicate that the null hypothesis can be rejected, which stated that no significant difference can be found between the phytolith morphological distribution from each of the vegetation types or biomes on the south coast of South Africa.

The ANOVA analysis also showed that parallelepiped blocky (ANOVA, $\mathrm{p}=0.0378$ ), spheroids (psilate and rugulate) (ANOVA, $\mathrm{p}=<.0001$ ) and restio phytoliths (ANOVA, $\mathrm{p}=<.0001$ ) are the defining phytolith morphotypes of limestone fynbos vegetation (Table A2 and Fig. 7). No other vegetation type showed this pattern (Fig. 7). These results are in agreement with those observed through the D/P and Fy indices (Fig. 6a and b). The post hoc Tukey's HSD test confirmed a clear separation among limestone fynbos vegetation and the rest of the vegetation types (Fig. 7). Contrariwise, the statistical analysis conducted did not show any defining phytolith morphotype in samples from sand and grassy fynbos (Table A2 and Fig. 7). Nevertheless grassy fynbos vegetation is characterized by the low presence of woody and restio elements (Fig. 7).

Renosterveld vegetation is characterized mainly by a very low presence of GSSC saddles (ANOVA, $\mathrm{p}=0.0024$ ), spheroids (psilate and rugulate) (ANOVA, $\mathrm{p}=0.0001$ ) and restio phytoliths (ANOVA, p=0.0001) (Table A2 and Fig. 7). The post hoc Tukey's HSD test showed that Renosterveld mainly differ from those vegetation types belonging to the Thicket biome regarding the presence of ellipsoids, GSSC saddles and irregular and indeterminate morphotypes, and with limestone and sand fynbos vegetation types regarding the presence of spheroids and restio 
phytoliths (Fig. 7).

ANOVA and post hoc Tukey's HSD test results identified hair base phytoliths (ANOVA, $\mathrm{p}=0.0195$ ) and ellipsoids (ANOVA, $\mathrm{p}=0.026$ ) as the defining morphotypes for subtropical thicket vegetation (Fig. 7). Coastal thicket vegetation is correlated with an abundance of GSSC saddles (ANOVA, $\mathrm{p}=0.0024$ ), irregular and indeterminate morphotypes (ANOVA, $\mathrm{p}=<.0001$ ), and spheroid echinates from the Arecaceae subfamily (Table A2 and Fig. 7). The statistical analysis did not show any defining phytolith distribution in samples from strandveld vegetation (Table A2 and Fig. 7). Finally, ANOVA and post hoc Turkey's HSD method demonstrated a clear separation of riparian vegetation among the other vegetation types by the abundance of GSSC saddles (ANOVA, p=0.0024) (Table A2 and Fig. 7).

When analyzing the phytolith assemblage in a broader scale (vegetation biomes) it was observed that ANOVA and post hoc Tukey's HSD test clearly differentiate the Fynbos biome from others local biomes. Like our results of the limestone fynbos vegetation, the Fynbos biome itself can be defined based on parallelepiped blockys (ANOVA, $\mathrm{p}=0.005$ ), spheroids psilate and rugulate (ANOVA, $\mathrm{p}=0.0021$ ), and restio phytoliths (ANOVA, $\mathrm{p}=0.0001$ ) (Table A3 and Fig. 8). ANOVA showed that Renosterveld biome is mainly characterized by the abundance of GSSC rondels (ANOVA, $\mathrm{p}=0.0128$ ) and a low presence of GSSC saddles (Fig. 8). The post hoc Tukey's HSD test showed that the highest differences in the presence of GSSC rondels are observed between Renosterveld and Fynbos biome (Fig. 8). Thicket biome is mainly characterized by the abundance of irregular and indeterminate morphotypes (ANOVA, $\mathrm{p}=0.0015$ ) as well as the abundance of spheroid echinate phytoliths (ANOVA, $\mathrm{p}=0.0103$ ). The post hoc Tukey's HSD test showed that Thicket vegetation can be clearly differentiate among biomes by the abundance in the presence of irregular phytoliths (ANOVA, p=0.0015) (Fig. 8). Finally, ANOVA showed that riparian vegetation is correlated with the abundance of GSSC saddles (ANOVA, $\mathrm{p}=0.0027$ ). The post hoc Tukey's HSD test showed that riparian vegetation differs mainly from Fynbos and Renosterveld biomes regarding GSSC saddle concentration and placed closely to the Thicket biome (Table A3 and Fig. 8).

\section{Discussion}

\subsection{Phytolith deposition and preservation in modern soils}

Pre- and postdepositional processes may affect phytolith deposition and preservation in soils (Piperno, 1988, 2006). Pre-depositional processes are the factors that may influence the plant accumulation in soils and their subsequent release of phytoliths after organic material decay. External factors like the degree of vegetation cover, the differential phytolith production in different plants, and the life cycles of specific plants have all been shown to influence the predeposition of phytoliths in modern soils (Piperno, 1988, 2006 and references therein). Other external factors may relate to wildlife and consumption of certain plant parts such as fruits or seeds, which when consumed will not contribute to the soil component. Aeolian or fire impact may also influence phytolith deposition in soils (see below).

South African grasses, for example, are high phytolith producers while other plants such as trees, shrubs, restios and most geophytes from the Iridaceae family are low phytolith producers 
(Esteban, unpublished data). Furthermore, phytoliths from the wood and bark of trees are often less well represented because these parts of the plants live longer and their tissues are not often deposited in the soils. In contrast, grasses and other herbaceous plants often contribute a higher phytolith input in soils because these plants have shorter life cycles. In areas with a dense understory it is therefore more likely to find phytoliths from graminoids and herbs rather than from the trees themselves.

Our analysis of the sediment samples from our study area showed a similar phytolith pattern. The samples that were collected from shrubby vegetation, such as limestone fynbos, dune cordon and strandveld, or samples that were collected from thicket (coastal thicket) did not contain high phytolith concentration. Conversely, samples from dense grassy vegetation, such as renosterveld and riparian vegetation, contained the highest phytolith concentration. The differences in these cases are less likely to be the product of actual vegetation changes rather than the dominance of grassy phytoliths at the expense of plants that produce much fewer phytoliths and the implication is that when grasses are present then it makes accurate vegetation identification more difficult.

After their deposition, preservation of phytoliths in modern soils is associated with the silicon cycle in which phytoliths are recycled by plant roots immediately upon their deposition in the soil A horizon (Alexandre et al., 1997, Derry et al., 2005). Soils with slow development and under constant biomass activity might have low preservation of the phytolith assemblage. Soils in the Southern Cape are from slightly fertile to infertile (Thwaites and Cowling, 1988), with a slow development and under a low biomass activity. We assume that the rate of deposition of phytoliths in fynbos vegetation (where perennial plants dominate) is lower than that of other types of vegetation with a large representation of grasses (annual plants). Consequently, the differences between the deposition rate and the rate of recycling of phytoliths in the fynbos vegetation account for their low concentration in soils.

Moreover, phytolith dissolution cannot be considered as cause for their low concentration in samples since all of the samples showed an acidic to a moderate alkaline $\mathrm{pH}$.

Low phytolith concentration in very coarse soils or in very active bioturbation soils has also been shown to be the result of phytolith translocation (e.g. Fiskish et al., 2010). These authors showed size dependence on phytolith percolation by water, with phytoliths with a size diameter of $5 \mu \mathrm{m}$ being the most susceptible to move downward. In our study, if phytolith translocation had occurred in our samples with low number of phytoliths (limestone fynbos, coastal thicket, strandveld vegetation types) then we would expect to not see small morphotypes, such as GSSC rondels and saddles or spheroids psilates and rugulates, what is not the case. Nonetheless, this should be further tested by analyzing the bottom of soil profiles.

The presence of restio phytoliths in some riparian plots where Restionaceae plants were not present might be related to the alluvial character of these soils, and thus, restio phytoliths might represent the runoff soil from up stream. Another likely explanation of its presence can be explained due to their transport in ash clouds after fire events in fynbos vegetation as it has been observed in other, although not-homologous, environments (Aleman et al., 2014). Thus, either water flow or aeolian transport or both could account for the small quantities of restio phytoliths in some riparian plots, despite the lack of restio plants. 


\subsection{Recognition of GCFR vegetation types through modern phytolith assemblages}

Fynbos constitutes one of the most characteristic vegetation types of the GCFR and thus the identification of key plants like restios and shrubby vegetation in fossil phytolith assemblages is critical to undertake accurate paleovegetation reconstructions. Our results showed that limestone fynbos can be characterized through the analyses of phytoliths from modern soils as well as by the identification of certain characteristic phytolith morphotypes (Fig. 7), such as restio phytoliths and spheroids. Our modern plant reference study, however, has shown that both restios (Table A1) and the wood of eudicot plants (e.g. Albert and Weiner, 2001; Tsartsidou et al., 2007; Esteban unpublished data) produce very few phytoliths per gram of plant material. The identification of these morphotypes in our samples may be related to their good preservation conditions. Previous studies have shown that the stability of phytolith morphotypes do differ from each other with spheroids showing the highest stability (Cabanes and Shahack-Gross, 2015). Whereas no dissolution experiments have been conducted on restio plants, their heavily silicified body suggests that they might be relatively stable in soils and sediments.

Fire regime is another important factor in fynbos ecology, but its role in phytolith deposition in soils has been discussed rarely. Fire regime is responsible for the decay of shrubby and herbaceous plants and the subsequent regeneration of shrubs and herbaceous plants. Because modern soil phytolith assemblages represent an amalgamation of the vegetation mosaic over a period of years to several decades, the effects of fire may favor a higher phytolith deposition rate in soils thereby increasing the representation of fynbos elements (shrubs and restios) in the phytolith record. Therefore, an increased presence of spheroids and restio phytoliths in fynbos soils - despite low phytolith production of eudicots and Restionaceae-might, in fact, be related to the effects of a persistent fire regime.

Furthermore, grass phytoliths were identified in all of our fynbos samples even though mature fynbos (i.e. unburnt for ca. 10-20 yr) is characterized by a restio understorey with few grasses. Grasses produce large amounts of phytoliths per gram of sediment (Albert and Weiner, 2001; Bamford et al., 2006; Tsartsidou et al., 2007; Esteban, unpublished data) and they are also most abundant immediately following burning episodes (Linder and Ellis, 1990). Thus, the effect of fire might be also responsible of leaving grass phytoliths as component of the soils.

In addition to the characterization of limestone vegetation, our study also showed how D/Po and Fy (high values) indices can be used for the identification of vegetation types with a high grass component, like grassy fynbos, renosterveld, and riparian vegetation (low values) (Fig. 6a and b). This observation is especially important because it provides insights into the true character of the paleo-vegetation regardless of any overbearing plant components. Sand fynbos samples, for example, showed a mean Fy index value of 0.6 with a high standard deviation of 0.5. This high deviation among samples is caused by the presence of grasses in samples SF11-42 and SF11-43, which showed a very low Fy values (Fig. 6b). These results show that when grasses are present, its occurrence might mask the correct identification of vegetation types what might constitute a problem facing paleoenvironmetal studies across South Africa.

Forest and Thicket biomes are characterized by dense vegetation and dominated by trees and 
shrubs that are often succulent. D/P (Alexandre et al., 1997; Barboni et al., 1999; Bremond et al., 2005a) and $\mathrm{D} / \mathrm{P}^{\circ}$ (Bremond et al., 2008) indices have been used to estimate the density of woody elements in different habitats in West and East Africa, but they have not been applied to South African studies. In our study, we found that low $\mathrm{D} / \mathrm{P}^{\circ}$ values $(<0,20)$ are not representative of dense tree and shrub vegetation from the Thicket and the Forest Biomes rather than being from Renosterveld and Strandveld (Fig. 6a). These findings imply that the $\mathrm{D} / \mathrm{P}^{\mathrm{o}}$ index may not be a useful tool to identify thicket or forest vegetation through fossil phytolith assemblages when working on the south coast of South Africa.

However, ANOVA and post host Tukey's HSD test showed that Thicket biome might be characterized by the abundance of irregular and other unknown phytolith morphotypes (probably produced by eudicot plants) as well as GSSC saddles as a secondary term (Table A3 and Fig. 8). In regards to vegetation types, the statistical analysis showed that epidermal hair base (from eudicot plants) and ellipsoid phytoliths are the defining features of subtropical thicket vegetation. Nevertheless, because few phytoliths were identified in these samples, results must be taken with caution. Similarly, the statistical analysis showed that coastal thicket vegetation might be characterized through fossil phytolith assemblages by the presence of GSSC saddles, spheroid echinates and irregular phytoliths (Table A2 and Fig. 7). Palms are not part of the vegetation from the GCFR, whereas spheroids echinate from the Arecaceae family were identified in samples from coastal thicket and strandveld vegetation, although in very low percentage. Arecaceae family produce large amount of phytoliths, namely the spheroid echinate morphotypes (Albert et al., 2009; Bamford et al., 2006). Thus the low amount recovered does not support the presence of these plants but seems to be more related to contamination by different factors, including human introduction of palms for horticulture in the area.

As GSSCs have been linked to different subfamilies, their morphotypes can be used to differentiate between $\mathrm{C}_{3}$ and $\mathrm{C}_{4}$ grasses and thus offer information on paleoecological conditions. We observed that even though all the samples from the different vegetation types show a mix of $\mathrm{C}_{3}$ and $\mathrm{C}_{4}$ GSSCs, there is a higher presence of GSSC rondels, ascribed to the $\mathrm{C}_{3}$ grass subfamilies such as Ehrhartoideae, Danthonoideae and Pooideae (Fig. 3). The statistical analysis showed a significant dominance of GSSC rondels in samples from Renosterveld biome.

GSSC lobates (mainly bilobates) have also been recovered in most of the samples from the different vegetation types while dominating in the sample collected from coastal forest in Brenton lake area (Table 2). GSSCs lobates are common in $C_{4}$ Panicoideae (Twiss et al., 1969), but have also been identified in the $\mathrm{C}_{3}$ Ehrhartoideae and Danthonioideae grasses (Cordova and Scott, 2010). Therefore, the grass attribution of bilobates should be made with caution. Despite our results indicating a clear dominance of GSSC lobates in Coastal forest vegetation, more samples from this vegetation are needed to corroborate the statistically significance of these results.

The $\mathrm{C}_{4}$ Chloridoideae subfamily is a short tropical subfamily adapted to dry climates and/or low available soil moisture (xeric environments) (Vogel et al., 1978; Tieszen et al., 1979). GSSC saddles, characteristic of $\mathrm{C}_{4}$ chloridoids, were identified in all the vegetation types but dominating in samples from riparian vegetation (ANOVA, $\mathrm{p}=0.0024$ ) and coastal thicket (ANOVA, $\mathrm{p}=0.0024$ ) (Fig. 7). These results correlate well with those from the Iph index, which showed a 
statistically significance correlation between high Iph index values and riparian vegetation (Fig. 6c). Cynodon dactylon would be a dominant grass in riparian (floodplain) habitats of the Gouritz valley and are generally very common between thicket clumps in coastal thicket areas. Thus the phytolith assemblage from riparian and coastal thicket vegetation seems to record the presence of this grass species. Furthermore, this species occurs on almost all soil types-but especially in fertile (loamy) soils - and it is common in disturbed areas like riparian environments. Consequently, our results demonstrate that the distribution of GSSC saddles in phytolith assemblages, as well as the Iph index, can be used for identifying riparian and coastal thicket habitats through the fossil phytolith record on the south coast of South Africa. Finally, distinguishing between both riparian and coastal thicket vegetation (Thicket Biome) might be assessed by the higher presence of irregular and unknown phytoliths probably from the eudicot group.

\section{Conclusions}

This study shows the potential and limitations for using phytolith assemblages from modern soils to reconstruct GCFR vegetation. We found that each of the vegetation types in our study are consistent with a mix of grass subfamilies from the $\mathrm{C}_{3}$ and the $\mathrm{C}_{4}$ photosynthetic pathway, which is consistent with the distribution of grasses in the Southern Cape. We also showed that the cooccurrence of restio phytoliths, high presence of spheroid morphotypes, and a high presence of rondel GSSCs from $\mathrm{C}_{3}$ grasses are the characteristic feature for the identification of fynbos vegetation, mainly limestone and sand fynbos. Our demonstration of the Fy index also showed that it can be used to identify limestone and sand fynbos vegetation through phytolith assemblages. However, as it was observed in samples SF11-42 and SF11-43, if grass plants are present in the vegetation, it is not possible to identify fynbos vegetation accurately. The D/ $\mathrm{P}^{\mathrm{o}}$ index was useful in identifying limestone fynbos vegetation, but it was not able to characterize other vegetation types, such as forest and shrubland/thicket.

Moreover, our results also provided key details on identifying specific GCFR vegetation types through phytolith analysis. In particular, coastal forest vegetation appears to be related to the dominance of GSSC lobates though a larger number of samples are needed to corroborate this association. Similarly, saddles from the $\mathrm{C}_{4}$ chloridoid grass subfamily may be used to identify riparian and coastal thicket vegetation when studying fossil phytolith assemblages. However, we contend that further studies focused on the vegetation types occurring in Western $\left(\mathrm{C}_{3}\right.$ dominance) and Eastern Cape $\left(\mathrm{C}_{4}\right.$ dominance $)$ are needed to fully understand the phytolith morphological distribution along different South African habitats with different environmental and climatic conditions. This, along with the results provided in this study, might contribute to our understanding of past environments and climate changes on the south coast of South Africa.

\section{Acknowledgements}

Field and laboratory work was supported by financial support from the Spanish Ministry of Science and Innovation and Economy and Competitivity (HAR2010-15967 and HAR201342054-P) and from the Catalan Government (2014-SGR0845). CWM acknowledges the support 
of the National Science Foundation (BCS-0524087, and BCS-1138073), the Hyde Family Foundation, and the Institute of Human Origins at Arizona State University. This research was also funded by the Oppenheimer Memorial Trust. We also thank the two anonymous reviewers for their constructive comments on the paper.

\section{References}

Albert, R.M., Weiner, S., 2001. Study of phytoliths in prehistoric ash layers using a quantitative approach, in: Meunier, J.D., Coline, F. (Eds.), Phytoliths: Applications in Earth Sciences and Human History. A.A. Balkema Publishers, Lisse, pp. 251-266.

Albert, R.M., Bamford, M., 2012. Vegetation during UMBI and deposition of Tuff IF at Olduvai Gorge, Tanzania (ca. 1.8 Ma) based on phytoliths and plant remains. Journal of Human Evolution $63,342-350$.

Albert, R.M., Marean, C.W., 2012. The exploitation of plant resources by early Homo sapiens: the phytolith record from Pinnacle Point 13B Cave, South Africa. Geoarchaeology 27(4), 363384.

Albert, R.M., Bamford, M.K., Cabanes, D., 2006. Taphonomy of phytoliths and mac- roplants in different soils from Olduvai Gorge (Tanzania) and the application to Plio-Pleistocene palaeoanthropological samples. Quaternary International 148, 78-94.

Albert, R.M., Bamford, M.K., Cabanes, D., 2009. Palaeoecological significance of palms at Olduvai Gorge, Tanzania, based on phytolith remains. Quaternary International 193, 41-48.

Albert, R.M., Bamford, M.K., Esteban, I. 2015. Reconstruction of ancient palm vegetation landscapes using a phytolith approach. Quaternary International 369, 51-66.

Albert, R. M., Ruíz, J. A., Sans, A. in press. PhytCore ODB: A new tool to improve efficiency in the management and exchange of information on phytoliths. Journal of Archaeological Science, Available online 12 December 2015, ISSN 0305-4403, http://dx.doi.org/10.1016/j.jas.2015.10.014.

Aleman, J.C., Canal-Subitani, S., Favier, C., Bremond, L., 2014. Influence of the local environment on lacustrine sedimentary phytolith records. Palaeogeography, Palaeoclimatology, Palaeoecology 414, 273-283.

Alexandre, A., Meunier, J.-D., Lézine, A.-M., Vincens, A., Schwartz, D., 1997. Phytoliths indicators of grasslands dynamics during the late Holocene in intertropical Africa. Palaeogeography, Palaeoclimatology, Palaeoecology 136, 213-219. 
Bamford, M.K., Albert, R.M., Cabanes, D., 2006. Assessment of the Lowermost Bed II PlioPleistocene vegetation in the eastern palaeolake margin of Olduvai Gorge (Tanzania) and preliminary results from fossil macroplant and phytolith remains. Quaternary International 148, 95-112.

Bamford, M.K., Stanistreet, I.G., Stollhofen, H., Albert, R.M., 2008. Late Pliocene grassland from Olduvai Gorge, Tanzania. Palaeogeography, Palaeoclimatology, Palaeoecology, 257(3), 280-293.

Barboni, D., Bremond, L., 2009. Phytoliths of East African grasses: An assessment of their environmental and taxonomic significance based on floristic data. Review of Palaeobotany and Palynology 158, (1-2), 29-41.

Barboni, D., Bonnefille, R., Alexandre, A., and Meunier, J., 1999. Phytoliths as paleoenvironmental indicators, west side Middle Awash Valley, Ethiopia. Palaeogeography, Palaeoclimatology, Palaeoecology 152, 87-100.

Barboni, D., Bremond, L., Bonnefille, R., 2007. Comparative study of modern phytolith assemblages from inter-tropical Africa. Palaeogeography Palaeoclimatology Palaeoecology 246, 454-470.

Barboni, D., Ashley, G.M., Dominguez-Rodrigo, M.Bunn, H.T., Mabulla, A.Z.P., Baquedano, E., 2010. Phytoliths infer locally dense and heterogeneous paleovegetation at FLK North and surrounding localities during upper Bed I time, Olduvai Gorge, Tanzania. Quaternary Research $74,344-354$.

Bar-Matthews, M., Marean, C.W., Jacobs, Z., Karkanas, P., Fisher, E.C., Herries, A.I.R., Brown, K., Williams, H.M., Bernatchez, J., Ayalon, A., Nilssen, P.J., 2010. A high resolution and continuous isotopic speleothem record of paleoclimate and paleoenvironment from 90 to $53 \mathrm{ka}$ from Pinnacle Point on the south coast of South Africa. Quaternary Science Review 29, 21312145.

Behar, D.M., Villems, R., Soodyall, H., Blue-Smith, J., Pereira, L., Metspalu, E., Scozzari, R., Makkan, H., Tzur, S., Comas, D., 2008. The Dawn of Human Matrilineal Diversity. The American Journal of Human Genetics 82, 1130-1140.

Bergh, N.G., Verboom, G.A., Rouget, M., Cowling, R.M., 2014. Vegetation types of the Greater Cape Floristic Region, in: Allsopp, N., Colville, J.F., Verboom, T., (Eds.), Fynbos: Ecology, Evolution, and Conservation of a Megadiverse Region. Oxford: Oxford University Press, pp. 125. 
Bremond, L., Alexandre, A., Hély, C., Guiot, J., 2005a. A phytolith index as a proxy of tree cover density in tropical areas: calibration with Leaf Area Index along a forest-savanna transect in southeastern Cameroon. Global and Planetary Change 45 (4), 277-293.

Bremond, L., Alexandre, A., Hély, C., Peyron, O, Guiot, J., 2005b. Grass water stress estimated from phytoliths in West Africa. Journal of Biogeography 32(2), 311-327.

Bremond, L., Alexandre, A., Wooller, M.J., Hély, C., Williamson, D., Schäfer, P.A., Majule, A., Guiot, J., 2008. Phytolith indices as proxies of grass subfamilies on East African tropical mountains. Global and Planetary Change 61(3) 209-224.

Brown, K.S., Marean, C.W., Herries, A.I., Jacobs, Z., Tribolo, C., Braun, D., Roberts, D.L., Meyer, M.C., Bernatchez, J., 2009. Fire as an engineering tool of early modern humans. Science $325,859-862$.

Brown, K.S., Marean, C.W., Jacobs, Z., Schoville, B.J., Oestmo, S., Fisher, E.C., Bernatchez, J., Karkanas, P., Matthews, T., 2012. An early and enduring advanced technology originating 71000 years ago in South Africa. Nature 491, 590-593.

Cabanes, D., Shahack-Gross, R., 2015. Understanding Fossil Phytolith Preservation: The Role of Partial Dissolution in Paleoecology and Archaeology. PLoS ONE 10(5): e0125532.

Clark, J.D., Beyene, Y., WoldeGabriel, G., Hart, W.K., Renne, P.R., Gilbert, H., Defleur, A., Suwa, G., Katoh, S., Ludwig, K.R., Boisserie, J.R., Asfaw, B., White, T.D., 2003. Stratigraphic, chrono- logical and behavioural contexts of Pleistocene Homo sapiens from Middle Awash, Ethiopia. Nature 423, 747-752.

Colville, J.F., Potts, A.J., Bradshaw, P.L., Measey, G.J., Snijman, D., Picker, M.D., Proches, Ş., Bowie, R.C.K., Manning, J.C., 2014. Floristic and faunal Cape biochoria: do they exist?, in: Fynbos: ecology, evolution, and conservation of a megadiverse region. Oxford University Press United Kingdom, pp. 73-92.

Cordova, C.E., 2013. C3 Poaceae and Restionaceae phytoliths as potential proxies for reconstructing winter rainfall in South Africa. Quaternary International 287, 121-140.

Cordova, C.E., Scott, L., 2010. The potential of Poaceae, Cyperaceae, and Restionaceae phytoliths to reflect past environmental conditions in South Africa. Palaeoecology of Africa. CRC Press Taylor and Francis Group, Boca Raton, Florida, pp.107-133.

d'Errico, F. Henshilwood, C.S., 2007. Additional evidence for bone technology in the southern 
African Middle Stone Age. Journal of Human Evolution 52, 142-163.

d'Errico, F., Henshilwood, C.S., Vanhaeren, M., van Niekerk, K., 2005. Nassarius kraussianus shell beads from Blombos Cave: evidence for symbolic behaviour in the Middle Stone Age. Journal of Human Evolution 48, 3-24.

De Vynck J.C., Van Wyk B.E., Cowling R.M., 2015. Indigenous edible plant use by contemporary Khoe-San descendants of South Africa's Cape South Coast. South African Journal of Botany 102, 60-69.

Deacon, H.J., Jury, M.R., Ellis, F., 1992. Selective regime and time, in: Cowling, R.M., (Ed.), The ecology of fynbos: nutrients, fire and diversity. Cape Town, South Africa: Oxford University Press, pp. 6-22.

Derry, L.A., Kurtz, A.C., Ziegler, K., Chadwick, O.A., 2005. Biological control of terrestrial silica cycling and export fluxes to watersheds. Nature 433,728-731.

Diester-Haass, L., Schrader, H.J., Thiede, J., 1973. Sedimentological and Paleoclimato- logical Investigations of Two Pelagic Ooze Cores off Cape Barbas, North-West Africa. Meteor ForshErgebnisse C16, pp. 19-66.

Dunn, R.E., Strömberg, C.A.E., Madden, R.H., Kohn, M.J., Carlini, A.A., 2015. Linked canopy, climate, and faunal change in the Cenozoic of Patagonia. Science 347(6219), 258-261.

Eichhorn, B., Neumann, K., Garnier, A., 2010. Seed phytoliths in West African Commelinaceae and their potential for palaeoecological studies. Palaeogeography, Palaeoclimatology, Palaeoecology 298, 300-310.

Engelbrecht, C.J., Landman, W.A., Engelbrecht, F.A., Malherbe, J., 2014. A synoptic decomposition of rainfall over the Cape south coast of South Africa. Climate Dynamics 44(9-10), 2589-2607.

Fagundes, N.J.R., Ray, N., Beaumont, M., Neuenschwander, S., Salzano, F.M., Bonatto, S.L., Excoffier, L., 2007. Statistical evaluation of alternative models of human evolution. Proceedings of the National Academy of Sciences 104, 17614.

Fahmy, A. G., 2008. Diversity of lobate phytoliths in grass leaves from the Sahel region, West Tropical Africa: Tribe Paniceae. Plant Systematics and Evolution 270, 1-23.

Fisher, E.C., Albert, R.M., Botha, G., Cawthra, H.C., Esteban, I., Harris, J., Jacobs, Z., Jerardino, A., Marean, C.W., Neumann, F.H., Pargeter, J., Poupart, M., Venter, J., 2013. Archaeological 
Reconnaissance for Middle Stone Age Sites Along the Pondoland Coast, South Africa. PaleoAnthropology 104-137.

Fiskish, O., Ingwersena, J., Lamers, M.,Denysenko, D., Streck, T., 2010. Phytolith transport in soil: a laboratory study on intact soil cores. European Journal of Soil Science 61, 445-455.

Fredlund, G.G., Tieszen, L.T., 1994. Modern phytolith assemblages from the North American Great Plains. Journal of Biogeography 21, 321-335.

Fredlund, G.G., Tieszen, L.L., 1997. Calibrating grass phytolith assemblages in climatic terms: application to late Pleistocene assemblages from Kansas and Nebraska. Palaeogeography, Palaeoclimatology, Palaeoecology 136, 199-211.

Garnier, A., Neumann, K., Eichhorn, B., Lespez, L., 2013. Phytolith taphonomy in the middle- to late-Holocene fluvial sediments of Ounjougou (Mali, West Africa). The Holocene 23(3), 416431.

Gonder, M.K., Mortensen, H.M., Reed, F.A., de Sousa. A., Tishkoff, S.A., 2007. Whole-mtDNA Genome Sequence Analysis of Ancient African Lineages. Molecular Biology and Evolution 24, 757-768.

Henshilwood, C.S., van Niekerk, K.L., 2014. Blombos Cave: The Middle Stone Age Levels, in: Smith, C., (Ed.), Encyclopedia of Global Archaeology. Springer, New York, pp. 915-922.

Henshilwood, C.S., d'Errico, F., Marean, C.W., Milo, R.G., Yates, R.J., 2001. An early bone tool industry from the Middle Stone Age, Blombos Cave, South Africa: implications for the origins of modern human behaviour, symbolism and language. Journal of Human Evolution 41, 631-678.

Henshilwood, C.S., d'Errico, F., Yates, R., Jacobs, Z., Tribolo, C., Duller, G.A. T., Mercier, N., Sealy, J.C., Valladas, H., Watts, I. Wintle, A.G., 2002. Emergence of modern human behavior: Middle Stone Age engravings from South Africa. Science 295, 1278-1280.

Henshilwood, C., d'Errico, F., Vanhaeren, M., van Niekerk, K., Jacobs, Z., 2004. Middle Stone Age Shell Beads from South Africa. Science 304, 404.

Jerardino, A. Marean, C.W., 2010. Shellfish gathering, marine palaeoecology and modern human behavior: perspectives from Cave PP13B, Pinnacle Point, South Africa. Journal of Human Evolution 59, 412-429.

Katz, O., Cabanes, D., Weiner,S., Maeir, A., Boaretto, E., Shahack-Gross, R., 2010. Rapid phytolith extraction for analysis of phytolith concentrations and assemblages during an 
excavation: an application at Tell es-Safi/Gath, Israel. Journal of Archaeological Science 37 (7), 1557-1563.

Kemper, J., Cowling, R.M., Richardson, D.M., Forsyth, G.G., McKelly, D.H., 2000. Landscape fragmentation in South Coast Renosterveld, South Africa, in relation to rainfall and topography. Austral Ecology 25(2), 179-186.

Linder, H.P., Ellis, R.P., 1990. A revision of Pentaschistis (Arundineae: Poaceae). Contributions from the Bolus Herbarium 12, 1-124.

Madella, M., Alexandre, A., Ball, T., 2005. International Code for Phytolith Nomenclature 1.0. Annals of Botany 96, 253-260.

Malan, J.A., 1987. The Bredasdorp Group in the area between Gans Bay and Mossel Bay. South African Journal of Science, 83, 506-507.

Marean, C.W., 2010. Pinnacle Point Cave 13B (Western Cape Province, South Africa) in context: The Cape Floral kingdom, shellfish, and modern human origins. Journal of Human Evolution 59 (3-4), 425-443.

Marean, C.W., 2011. Coastal South Africa and the co-evolution of the modern human lineage and coastal adaptations. Settlement, in: Bicho, N., Haws, J.A., Davis, L.G., (Eds.), Trekking the Shore: Changing Coastlines and the Antiquity of Coastal. Springer, New York, pp. 421-440.

Marean, C.W., Bar-Matthews, M., Bernatchez, J., Fisher, E.C., Goldberg, P., Herries, A.I., Jacobs, Z., Jerardino, A., Karkanas, P., Minichillo, T., 2007. Early human use of marine resources and pigment in South Africa during the Middle Pleistocene. Nature 449, 905-908.

Marean, C.W., Cawthra, H.C., Cowling, R.M., Esler, K.L., Fisher, E., Milewski, A., Potts, A.J., Singels, E., De Vynck, J., 2014. Stone Age people in a changing South African Greater Cape Floristic Region, in: Allsopp, N., Colville, J.F., Verboom, G.A., (Eds.), Fynbos: Ecology, Evolution, and Conservation of a Megadiverse Region. Oxford University Press.

Matthews, T., Rector, A., Jacobs, Z., Herries, A.I.R., Marean, C.W., 2011. Environmental implications of micromammals accumulated close to the MIS 6 to MIS 5 transition at Pinnacle Point Cave 9 (Mossel Bay, Western Cape Province, South Africa). Palaeogeography, Palaeoclimatology, Palaeoecology 302, 213-29.

McDougall, I., Brown, F.H., Fleagle, J.G., 2005. Stratigraphic placement and age of modern humans from Kibish, Ethiopia. Nature 433, 733-736. 
Menge, B.A. Branch, G.M., 2001. Rocky Intertidal Communities, in; Bertness, M.D., Gaines, S.D., Hay, M.E., (Eds.), Marine community ecology. Sinauer Associates, Sunderland, pp. 221251.

Mercader, J., Bennett, T., Esselmont, C., Simpson, S., Walde, D., 2009. Phytoliths in woody plants from the miombo woodlands of Mozambique. Annals of Botany 104, 91-113.

Mercader, J., Astudillo, F., Barkworth, M., Bennett, T., Esselmont, C., Kinyanjui, R., Grossman, D.L., Simpson, S., Walde, D., 2010. Poaceae phytoliths from the Niassa Rift, Mozambique. Journal of Archaeological Science 37(8), 1953-1967.

Mercader, J., Bennett, T., Esselmont, C., Simpson, S., Walde, D., 2011. Soil phytoliths from miombo woodlands in Mozambique. Quaternary Research 75(1), 138-150.

Mulholland, S.C., Rapp, C.Jr., 1992. A morphological classification of grass silica-bodies, in: Rapp, Jr.G., Mulholland, C.S. (Eds.), Phytolith Systematics. Emerging Issues, Advances in Archaeological and Museum Science. Plenum Press, New York, pp. 65-89.

Mucina, L., Rutherford, M.C., 2006. The Vegetation Map of South Africa, Lesotho and Swaziland. SANBI, Pretoria.

Neumann, K., Fahmy, A., Lespez, L., Ballouche, A., Huysecom, E., 2009. The Early Holocene palaeoenvironment of Ounjougou (Mali): Phytoliths in a multiproxy context. Palaeogeography, Palaeoclimatology, Palaeoecology 276(1), 87-106.

Novello, A., Barboni, D., 2015. Grass inflorescence phytoliths of useful species and wild cereals from sub-Saharan Africa. Journal of Archaeological Science 59, 10-22.

Novello, A., Barboni, D., Berti-Equille, L., Mazur, J. C., Poilecot, P., Vignaud, P., 2012. Phytolith signal of aquatic plants and soils in Chad, Central Africa. Review of Palaeobotany and Palynology 178, 43-58.

Novello, A., Lebatard, A. E., Moussa, A., Barboni, D., Sylvestre, F., Bourlès, D.L., Paillès, C., Buchet, G., Decarreau, A., Duringer, P., Ghienne, J.F., Maley, J., Mazur, J.C. Roquin, C., Schuster, M., Vignaud, P., 2015. Diatom, phytolith, and pollen records from a $10 \mathrm{Be} / 9 \mathrm{Be}$ dated lacustrine succession in the Chad basin: Insight on the Miocene-Pliocene paleoenvironmental changes in Central Africa. Palaeogeography, Palaeoclimatology, Palaeoecology 430, 85-103.

Parr, J.F., Dolic, V., Lancaster, G., Boyd, W.E., 2001. A microwave digestion method for the extraction of phytoliths from herbarium specimens. Review of Palaeobotany and Palynology, 116(3), 203-212. 
Piperno, D.R., 1988. Phytolith analysis: An Archaeological and Geological Perspective. San Diego, Academic Press.

Piperno, D.R., 2006. Phytoliths: A comprehensive guide for archaeologists and paleoecologists. Lanham, MD: AltaMira Press.

Radomski, K.U., Neumann, K., 2011. Grasses and grinding stones: Inflorescence phytoliths from modern West African Poaceae and archaeological stone artefacts, in: Fahmy, A.G., Kahlheber, S., D'Andrea, A.C. (Eds.), Windows on the African Past. Current Approaches to African Archaeobotany. Frankfurt am Main: Africa Magna Verlag, pp. 153-166.

Rebelo, A.G., Cowling, R.M., Campbell, B.M., Meadows, M.E., 1991. Plant communities of the Riversdale Plain. South African Journal of Botany 57, 10-18.

Rogers, J.C., 1984. The association between the North Atlantic Oscillation and the Southern Oscillation in the northern hemisphere. Monthly Weather Review 112(10), 1999-2015.

Rossouw, L., 2009. The application of fossil grass-phytolith analysis in the reconstruction of late Cainozoic environments in the South African interior. Doctoral dissertation, University of the Free State.

Runge, F., 1996. Leaf phytoliths and silica skeletons from East African plants. CD-Rom Database. Germany, Department of Physical Geography, University of Paderborn.

Runge, F., 1999. The opal phytolith inventory of soils in central Africa-quantities, shapes, classification, and spectra. Review of Palaeobotany and Palynology, 107(1), 23-53.

Runge, F., Runge, J., 1997. Opal phytoliths in East African plants and soils. The state-of-the-art of phytoliths in soils and plants. Madrid: Centro de Ciencias Medioambientales, 71-81.

Schlebusch, C.M., Skoglund, P., Sjödin, P., Gattepaille, L.M., Hernandez, D., Jay, F., Li, S., de Jongh, M., Singleton, A., Blum, M.G.B., Soodyall, H., Jakobsson, M., 2012. Genomic Variation in Seven Khoe-San Groups Reveals Adaptation and Complex African History. Science, 338(6105), 374-379.

Schlebusch, C.M., Lombard, M., Soodyall, H., 2013. MtDNA control region variation affirms diversity and deep sub-structure in populations from southern Africa. BMC Evolutionary Biology 13(1), 56. 
Smith, T.M., Tafforeau, P., Reid, D.J., Grün, R., Eggins, S., Boutakiout, M., Hublin, J.J., 2007. Earliest evidence of modern human life history in North African early Homo sapiens. Proceedings of the National Academy of Sciences 104, 6128-6133.

Strömberg, C.A.E., 2002. The origin and spread of grass-dominated ecosystems in the Late Tertiary of North America: preliminary results concerning the evolution of hypsodonty. Palaeogeography, Palaeoclimatology, Palaeoecology 177, 59-75.

Strömberg, C.A.E., 2004. Using phytolith assemblages to reconstruct the origin and spread of grass-dominated habitats in the great plains of North America during the late Eocene to early Miocene. Palaeogeography, Palaeoclimatology, Palaeoecology 207, 239-275.

Strömberg, C.A.E., McInerney, F.A., 2011. The Neogene transition from C3 to C4 grasslands in North America: assemblage analysis of fossil phytoliths. Paleobiology 37(1), 50-71.

Strömberg, C.A.E., Werdelin, L., Friis, E.M., Saraç, G., 2007. The spread of grass-dominated habitats in Turkey and surrounding areas during the Cenozoic: Phytolith evidence, Palaeogeography, Palaeoclimatology, Palaeoecology 250 (1-4), 18-49.

Texier, P.J., Porraz, G., Parkington, J., Rigaud, J.P., Poggenpoel, C., Miller, C., Tribolo, C., Cartwright, C., Coudenneau, A., Klein, R., Steele, T., Verna, C., 2010. A Howiesons Poort tradition of engraving ostrich eggshell containers dated to 60,000 years ago at Diepkloof Rock Shelter, South Africa. Proceedings of the National Academy of Sciences 107, 6180-6185.

Thwaites, R.N., Cowling, R.M., 1988. Soil-vegetation relationships on the Agulhas plain, South Africa. Catena 15(3), 333-345.

Tieszen, L.L., Senyimba, M.M., Imbamba, S.K., Troughton, J. H., 1979. The distribution of C3 and $\mathrm{C} 4$ grasses and carbon isotope discrimination along an altitudinal and moisture gradient in Kenya. Oecologia 37(3), 337-350.

Tsartsidou, G., Lev-Yadun, S., Albert, R.M., Miller-Rosen, A., Efstratiou, N., Weiner, S., 2007. The phytolith archaeological record: strengths and weaknesses evaluated based on a quantitative modern reference collection from Greece. Journal of Archaeological Science 34(8), 1262-1275.

Twiss, P.C., 1987. Grass-opal phytoliths as climatic indicators of the Great Plains Pleistocene. Quaternary Environments of Kansas 5, 179-188.

Twiss, P.C., 1992. Predicted world distribution of C3 and C4 grass phytoliths, in: Rapp, G.Jr., Mulholland, S.C. (Eds), Phytolith Systematics: Emerging Issues, Advances in Archaeological and Museum Science. Plenum Press, New York, pp. 113-128. 
Twiss, P.C., Suess, E., Smith, R.M., 1969. Morphological classification of grass phytoliths. Soil Science Society of America Journal 33, 109-115.

Vlok, J.H.J., De Villiers, M.E., 2007. Vegetation map for the Riversdale domain. Unpublished 1:50 000 maps and report supported by the CAPE Fine Scale Planning Task Team and CapeNature.

Vogel, J.C., Fuls, A., Ellis, R.P., 1978. Geographical distribution of Kranz grasses in South Africa. South African Journal of Science 74, 209-215.

Watts, I., 1999. The origin of symbolic culture. in: Dunbar, R., Knight, C., Power, C. (Eds.), The Evolution of Culture. Edinburgh University Press, Edinburgh, pp. 113-146.

Watts, I., 2002. Ochre in the Middle Stone Age of southern Africa: ritualized display or hide preservative?. South African Archaeological Bulletin 57, 1-14.

Watts, I., 2010. The pigments from Pinnacle Point Cave 13B, Western Cape, South Africa. Journal of Human Evolution 59(3), 392-411.

White, T.D., Asfaw, B., DeGusta, D., Gilbert, H., Richard, G.D., Suwa, G., Howell, F.C., 2003. Pleistocene Homo sapiens from Middle Awash, Ethiopia. Nature 423, 742-747. 


\section{Figure caption}

Figure 1. Map showing the location of the modern surface soil samples by vegetation types and the major GCFR biomes after Mucina and Rutherfore (2006).

Figure 2. Microphotographs of phytoliths identified in samples analyzed. Pictures taken at 400x. a) prickle (RV10-04), b) bulliform cell (GF10-10), c) elongate with echinate margin (RV11-58), d-f) rondel GSSCs (SF11-42, SF11-43 and RV11-15), g-h) bilobates GSSCs (GF10-14, CF1013), i) saddle GSSCs (CT06-05), j) epidermal ground mass polyhedral (STV11-01), k) eudicot hair cell (SF11-37), 1) sclerenchyma (RP11-59). Scale bar represents $10 \mu \mathrm{m}$.

Figure 3. Ternary plot showing the grass silica short cells, grouped by the three fundamental categories: rondels, lobates and saddles, distribution among vegetation types. Rondel category includes also the oblong morphotypes. Legend: CT, coastal thicket; GF, grassy fynbos; LF, limestone fynbos; RP, riparian; RV, renosterveld; SF, sand fynbos; StT, subtropical thicket; STV, strandveld.

Figure 4. Microphotographs of four restio phytoliths identified in modern soils and Restionaceae modern plants. Phytoliths are shown from three different points of view by its rotation on the slide. Pictures taken at 400x. a-c) large spheroid showing protuberances, with granulate decoration (LF11-68); d-f) spheroids showing spiraling decoration (LF11-85); g-i) spheroid showing protuberances, with granulate/verrucate decoration (Thamnochortus insignis); j-1) spheroids showing spiraling decoration with a double ring on the edges (Elegia juncea). Scale bar represents $10 \mu \mathrm{m}$.

Figure 5. Microphotographs of phytoliths spheroids psilate and rugulate identified in Restionaceae plants (a-d) and the wood and bark of eudicot plants (e-h). Pictures taken at 400x. a-b) Restio triticeus, c-d) Thamnochortus insignis, e) Protea lanceolata, f) Leucospermum praecox, g) Elytropappus rhinocerotis and h) Protea repens. Scale bar represents $10 \mu \mathrm{m}$.

Figure 6. Box plot showing the phytolith indices values among vegetation types. a) $\mathrm{D} / \mathrm{P}^{\mathrm{o}}$ index [ $\sum$ (psilate and rugulate spheroids)/grass silica short cells] and the standard deviation among the different vegetation types; b) Fy index [ $\sum$ (psilate and rugulate spheroids and restio phytoliths)/grass silica short cells] and the standard deviation among the different vegetation types; c) Iph index [GSSC saddles/ $\sum$ (GSSC saddles and lobates)]; d) Ic index [GSSC rondels and oblongs/ $\sum$ (GSSC rondels, lobates and saddles)]. The mean values (mid-line), standard error \pm (box) and standard deviation (whiskers) are given for the four indices. Legend: LF, limestone fynbos; SF, sand fynbos; GF, grassy fynbos; RV, renosterveld; StT, subtropical thicket; CT, coastal thicket; STV, strandveld; RP, riparian. Different letters indicate means that are significantly different based on a Kruskal-Wallis test.

Figure 7. Box-plots of the nine phytolith morphotypes pointed out by ANOVA and a post hoc Tukey Honest Significant Differences (HSD) as statistically significant different among vegetation types. Legend: CT, coastal thicket; GF, grassy fynbos; LF, limestone fynbos; RP, riparian; RV, renosterveld; SF, sand fynbos; StT, subtropical thicket; STV, strandveld. Different letters indicate means that are significantly different based on the post hoc Tukey (HSD) test. 
Figure 8. Box-plots of the eight phytolith morphotypes pointed out by ANOVA and a post hoc Tukey Honest Significant Differences (HSD) as statistically significant different among vegetation biomes. Different letters indicate means that are significantly different based on the post hoc Tukey (HSD) test. 


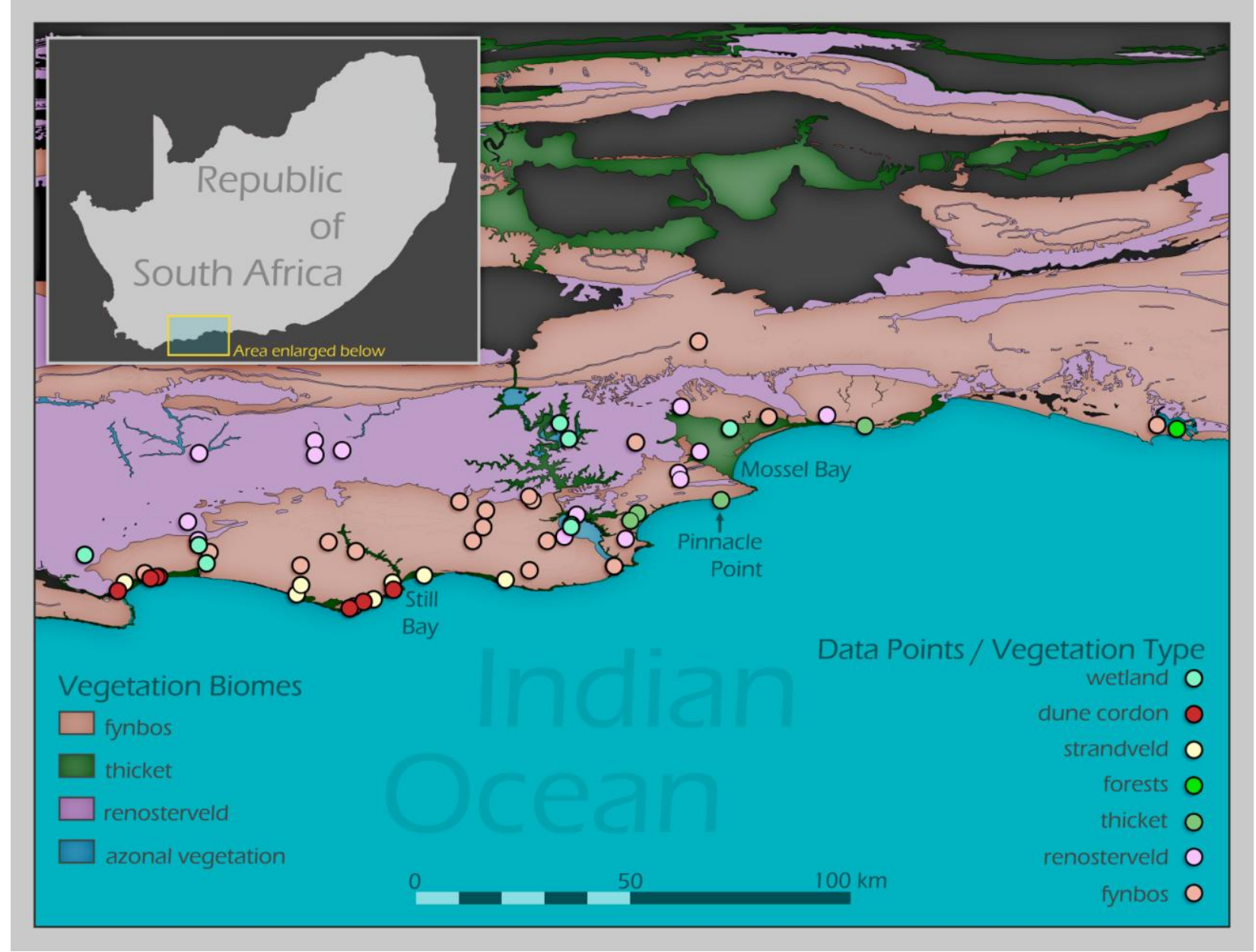



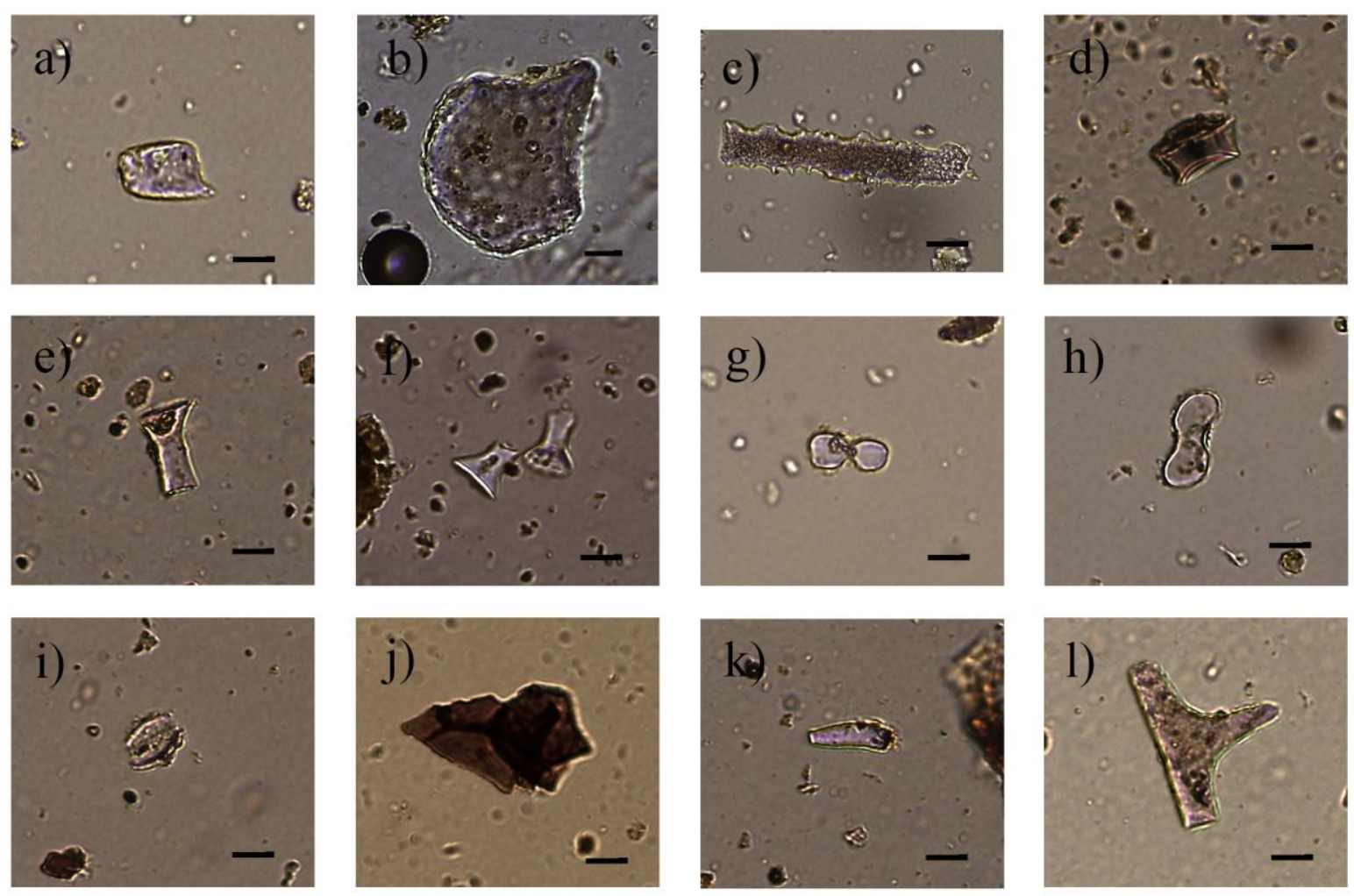


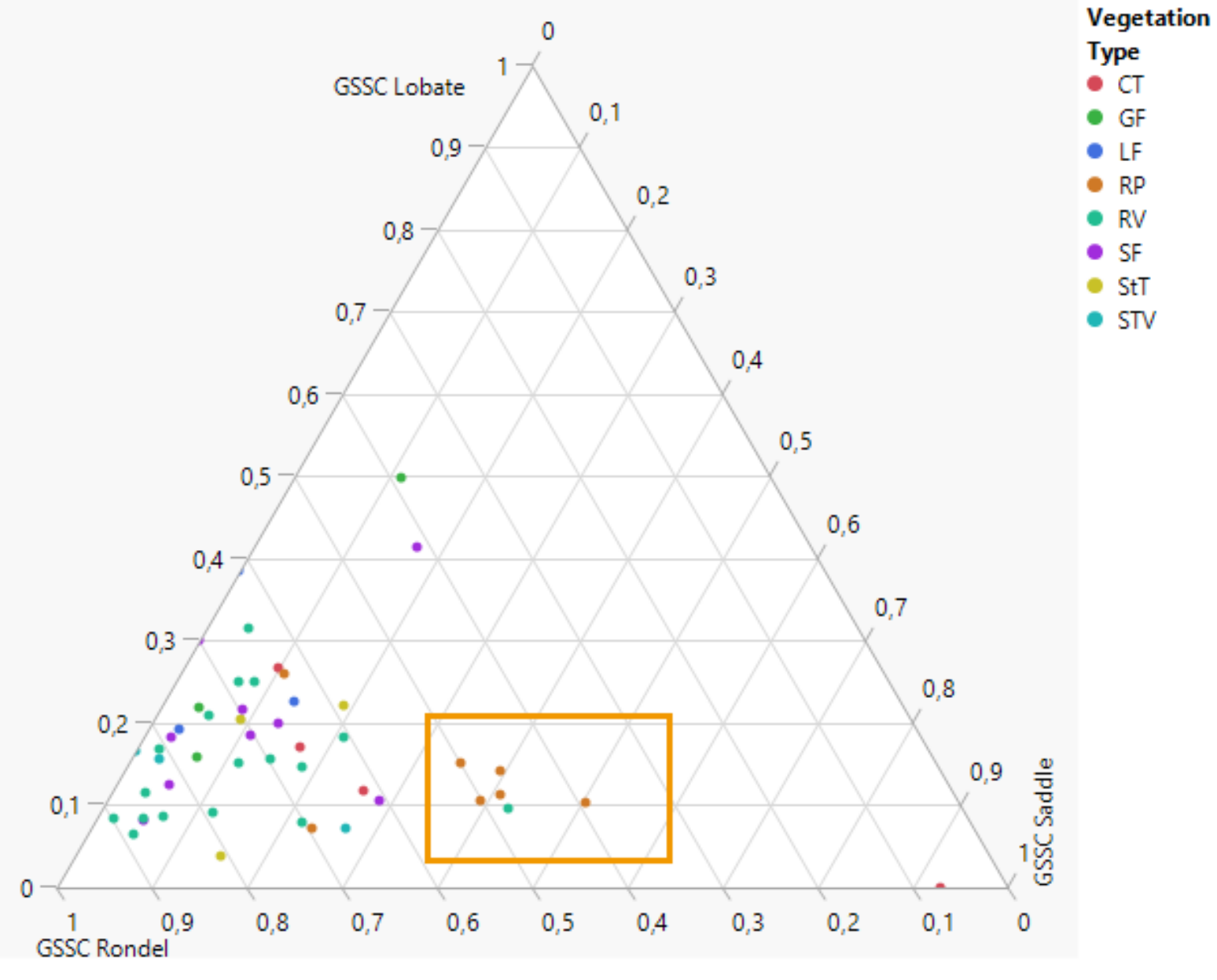



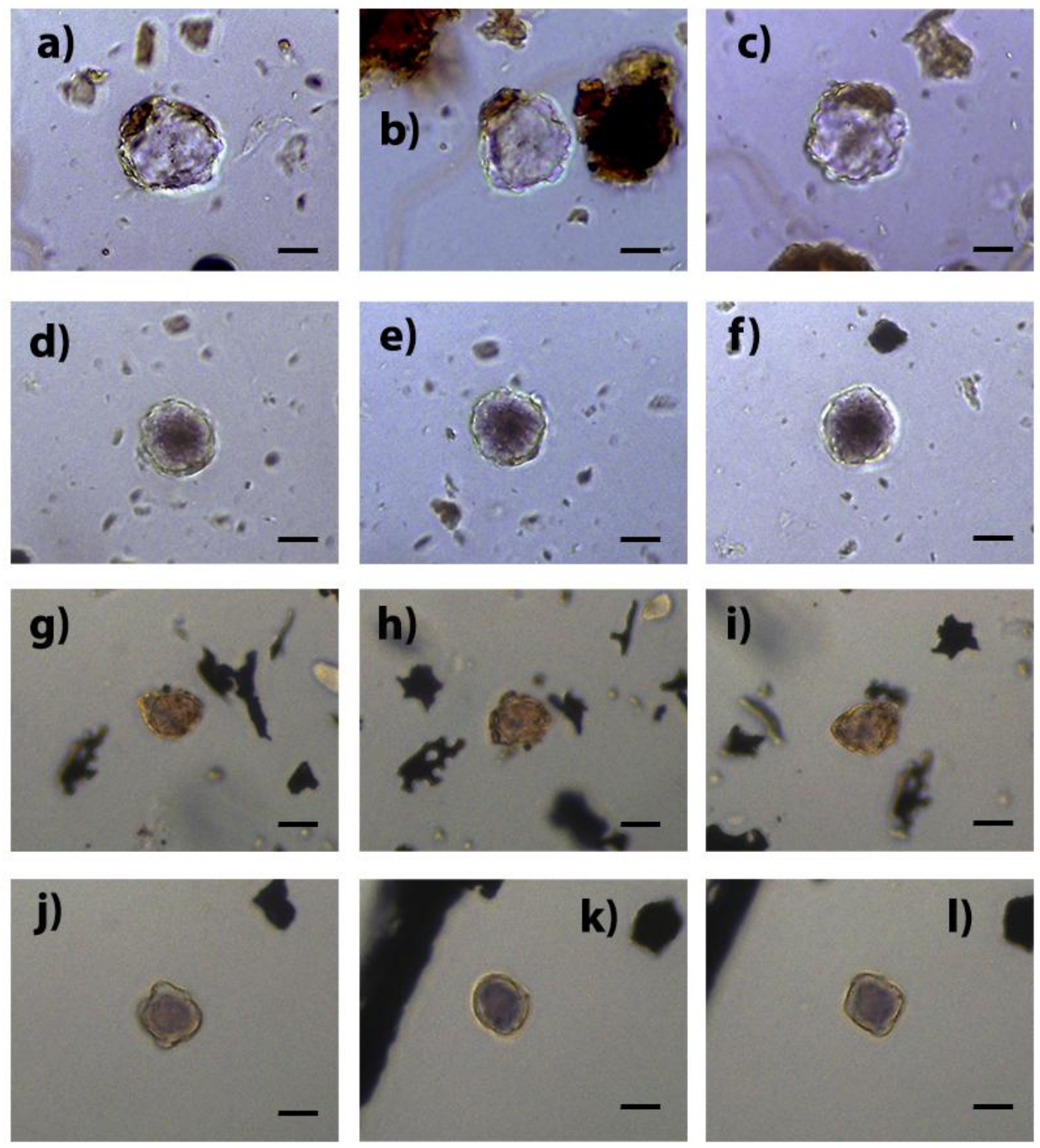

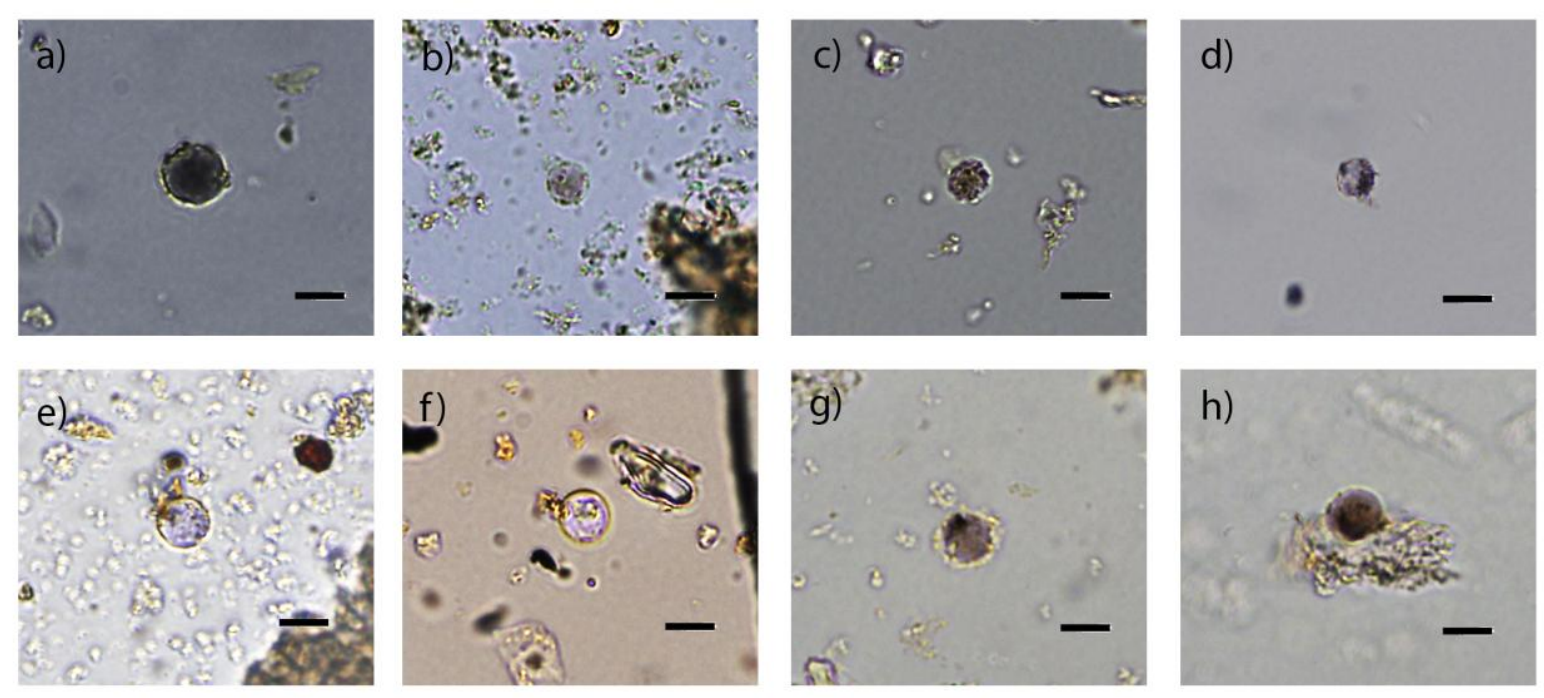

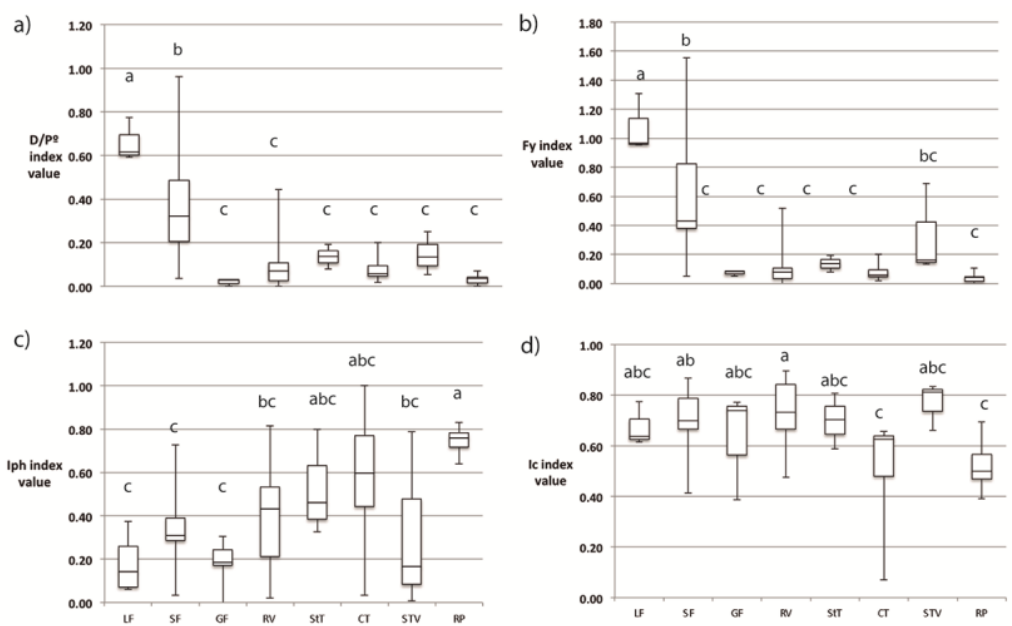

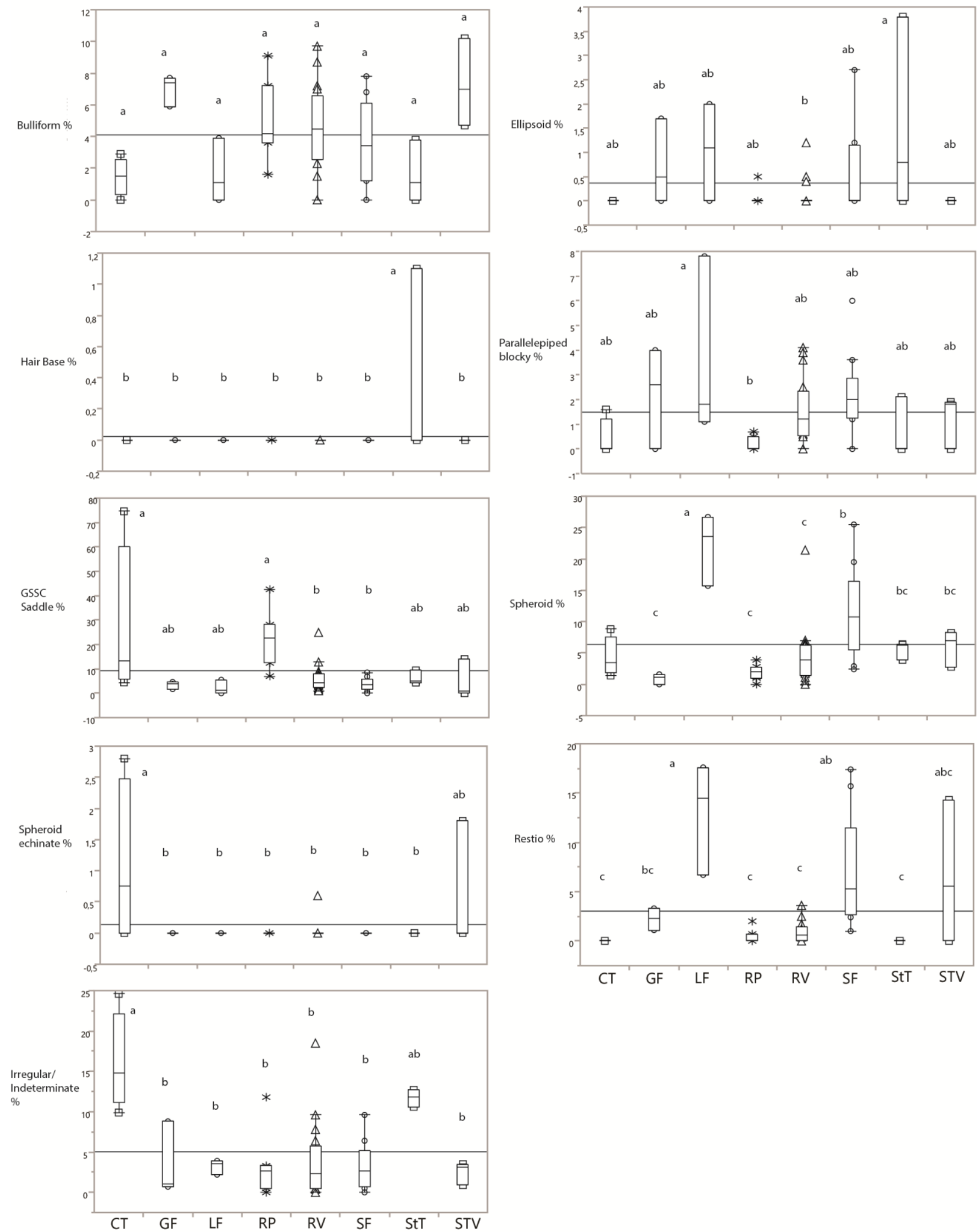

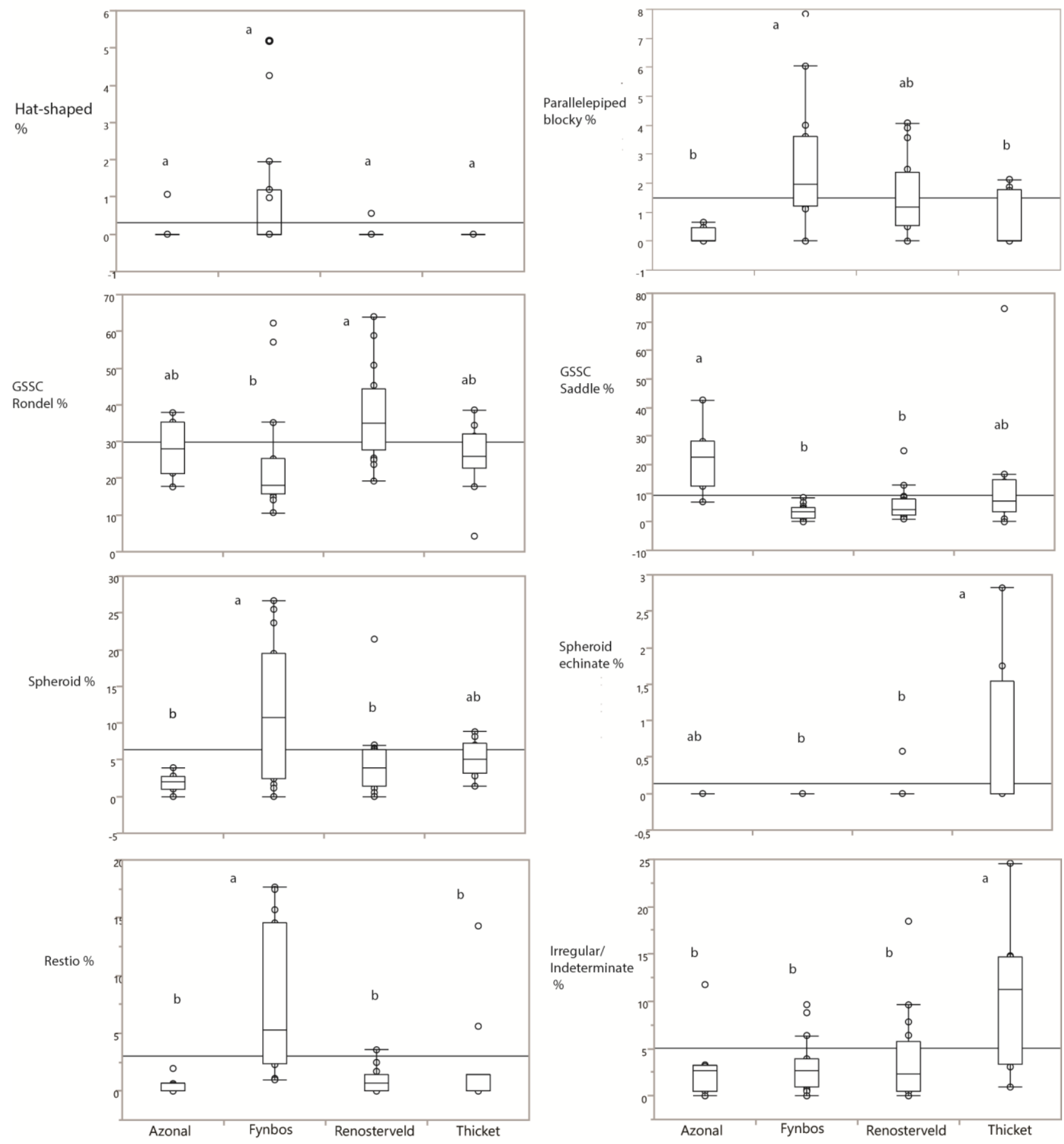
Table 1. Description of samples provenance and main phytolith results: soil type and soil pH, estimated number of phytoliths per gram of sediment, total number of phytoliths identified, percentage of weathered morphotypes and $\mathrm{D} / \mathrm{P}^{\mathrm{o}}$, Fy, Iph and Ic indices

\begin{tabular}{|c|c|c|c|c|c|c|c|c|c|c|c|c|}
\hline Sample number & Vegetation type & $\begin{array}{l}\text { Coordinates } \\
\text { (Long, Lat) }\end{array}$ & Dominant taxa & Soil type & Soil pH & $\begin{array}{l}\text { Estimated \# of } \\
\text { phytoliths g/sed }\end{array}$ & $\begin{array}{l}\text { \# Phytoliths } \\
\text { identified }\end{array}$ & $\begin{array}{l}\text { \% Weathered } \\
\text { morphotypes }\end{array}$ & $\mathrm{D} / \mathrm{P}^{\mathrm{o}}$ index & Fy index & Iph index & Ic index \\
\hline \multicolumn{13}{|l|}{ Fynbos biome } \\
\hline LF11-19 & Limestone fynbos & $\begin{array}{l}- \\
34,42828333 \\
21,3311\end{array}$ & $\begin{array}{l}\text { Restionaceae; Asteraceae; } \\
\text { Carpobrotus acinaciformus }\end{array}$ & Sand & 7.6 & 7,700 & 22 & 15 & - & - & - & - \\
\hline LF11-23 & Limestone fynbos & $\begin{array}{l}- \\
34,34333333 \\
21,2214\end{array}$ & $\begin{array}{l}\text { Themeda triandra; Olea europea subs. } \\
\text { Africana; Restionaceae }\end{array}$ & Sand & 7.3 & 60,000 & 97 & 0 & 0.8 & 1.0 & 0.1 & 0.8 \\
\hline LF11-25 & Limestone fynbos & $\begin{array}{l}- \\
34,29508333, \\
21,27883333\end{array}$ & $\begin{array}{l}\text { Restionaceae; Protea repens; } P . \\
\text { obtusifolium; Leucadendron } \\
\text { platyspermum }\end{array}$ & Sand & 7.2 & 74,000 & 30 & 4 & - & - & - & - \\
\hline LF11-26 & Limestone fynbos & $\begin{array}{l}- \\
34,31408333 \\
21,33561667\end{array}$ & Restionaceae; Erica sp; Asteraceae & Sand & 7.5 & 61,000 & 21 & 0 & - & - & - & - \\
\hline LF11-68 & Limestone fynbos & $\begin{array}{l}- \\
34,31581667, \\
21,03331667\end{array}$ & $\begin{array}{l}\text { Leucadendron coniferum; } \\
\text { Restionaceae }\end{array}$ & Sand & 7 & 160,000 & 62 & 5.6 & 0.6 & 1.3 & 0.0 & 0.6 \\
\hline LF11-74 & Limestone fynbos & $\begin{array}{l}-34,35955 \\
20,89986667\end{array}$ & $\begin{array}{l}\text { Leucadendron coniferum; } \\
\text { Restionaceae }\end{array}$ & Sand & 7.6 & 69,000 & 49 & 8.9 & - & - & - & - \\
\hline LF11-85 & Limestone fynbos & $\begin{array}{l}- \\
34,29261667, \\
21,7305\end{array}$ & Restionaceae & Sand & 7.3 & 71,000 & 68 & 5.2 & 0.6 & 1.0 & 0.4 & 0.6 \\
\hline SF10-05 & Sand fynbos & $\begin{array}{l}-34,34465 \\
21,86868333\end{array}$ & Freesia sp. & Sand & 5.8 & 99,000 & 83 & 3.5 & 0.4 & 0.4 & 0.4 & 0.7 \\
\hline SF10-06 & Sand fynbos & $\begin{array}{l}- \\
34,34513333, \\
21,86923333\end{array}$ & Restionaceae & Sand & 5.9 & 690,000 & 74 & 7.5 & 0.2 & 0.4 & 0.3 & 0.4 \\
\hline SF11-37 & Sand fynbos & $\begin{array}{l}-34,35335 \\
21,69413333\end{array}$ & $\begin{array}{l}\text { Leucadendron salignum; } \\
\text { Leucospermum praecox; Restionaceae }\end{array}$ & Sand & 5.3 & 300,000 & 89 & 2.5 & 0.7 & 0.8 & 0.3 & 0.7 \\
\hline SF11-42 & Sand fynbos & $\begin{array}{l}- \\
34,20858333 \\
21,70006667\end{array}$ & Poaceae; Aloe ferox; Osyris compressa & Sand & 3.5 & $2,900,000$ & 211 & 1.4 & 0.0 & 0.0 & 0.3 & 0.8 \\
\hline SF11-43 & Sand fynbos & $\begin{array}{l}-34,20115 \\
21,69343333\end{array}$ & $\begin{array}{l}\text { Elytropappus rhinocerotis; Erica; } \\
\text { Poaceae; Schotia afra }\end{array}$ & Loam & 4.4 & $1,290,000$ & 210 & 0.5 & 0.0 & 0.1 & 0.4 & 0.9 \\
\hline SF11-45 & Sand fynbos & $\begin{array}{l}- \\
34,22953333 \\
21,6038\end{array}$ & $\begin{array}{l}\text { Leucadendron salignum; Protea } \\
\text { repens; Leucospermum praecox; Erica } \\
\text { sp. }\end{array}$ & Sand & 4.8 & $1,000,000$ & 163 & 3.9 & 0.5 & 1.3 & 0.1 & 0.8 \\
\hline SF11-47 & Sand fynbos & $\begin{array}{l}-34,2928 \\
21,5772\end{array}$ & $\begin{array}{l}\text { Leucospermum praecox; Erica spp; } \\
\text { Leucadendron spp. }\end{array}$ & Sand & 5.8 & 290,000 & 109 & 1 & 1.0 & 1.6 & 0.4 & 0.7 \\
\hline SF11-62 & Sand fynbos & $\begin{array}{l}- \\
34,21151667, \\
21,5496\end{array}$ & $\begin{array}{l}\text { Restionaceae; Leucospermum muirii; } \\
\text { Brunia }\end{array}$ & Sand & 4.2 & 225,000 & 109 & 7.8 & 0.3 & 0.5 & 0.7 & 0.6 \\
\hline
\end{tabular}




\begin{tabular}{|c|c|c|c|c|c|c|c|c|c|c|c|c|}
\hline SF11-82 & Sand fynbos & $\begin{array}{l}-34,26395 \\
21,59831667\end{array}$ & $\begin{array}{l}\text { Thamnochortus insignis; } \\
\text { Leucadendron galpinii; } \\
\text { Leucospermum praecox }\end{array}$ & Sand & 5.3 & 154,000 & 93 & 5.7 & 0.3 & 0.4 & 0.0 & 0.7 \\
\hline GF10-10 & Grassy fynbos & $\begin{array}{l}- \\
34,08936667, \\
21,91323333\end{array}$ & $\begin{array}{l}\text { Themeda triandra; Eragostris } \\
\text { capensis; E. curvula }\end{array}$ & Sand & 5.5 & $2,330,000$ & 182 & 7.6 & 0.0 & 0.0 & 0.3 & 0.8 \\
\hline GF10-11 & Grassy fynbos & $\begin{array}{l}-34,08915 \\
21,91358333\end{array}$ & Pentaschistis colorata & Sand & 5.9 & $2,340,000$ & 175 & 6.4 & 0.0 & 0.1 & 0.2 & 0.7 \\
\hline GF10-14 & Grassy fynbos & $\begin{array}{l}-34,0533 \\
22,99021667\end{array}$ & Poaceae & Sand & 5.9 & $1,310,000$ & 153 & 4.4 & 0.0 & 0.1 & 0.2 & 0.4 \\
\hline MF12-01 & Mountain fynbos & $\begin{array}{l}-33.880 .997 \\
22.043 .091\end{array}$ & Restionaceae; Cyperaceae & Sand & 5 & 900,000 & 127 & 0 & 0.2 & 0.2 & 0.2 & 0.9 \\
\hline F/RV10-07 & Fynbos/Renosterveld & $\begin{array}{l}- \\
34,03696667, \\
22,18781667\end{array}$ & Tritoniopsis spp. Restionaceae & Sand & 5.5 & $1,890,000$ & 115 & 2.8 & 0.3 & 0.3 & 0.7 & 0.4 \\
\hline \multicolumn{13}{|c|}{ Renosterveld biome } \\
\hline RV09-01 & Renosterveld & $\begin{array}{l}- \\
34,15241389, \\
22,0015\end{array}$ & $\begin{array}{l}\text { Themeda tiandra; Brachiaria serrate; } \\
\text { Eragrostis sp. }\end{array}$ & Loam & 5.4 & $2,410,000$ & 155 & 27.7 & 0.1 & 0.1 & 0.2 & 0.7 \\
\hline RV09-02 & Renosterveld & $\begin{array}{l}- \\
22,15241389,\end{array}$ & Restionaceae; Poaceae & Loam & 5.2 & $1,980,000$ & 172 & 11.4 & 0.1 & 0.1 & 0.7 & 0.7 \\
\hline RV09-03 & Renosterveld & $\begin{array}{l}- \\
34,15229444, \\
22,00163056\end{array}$ & $\begin{array}{l}\text { Elytropappus rhinocerotis; Searsia } \\
\text { lucida }\end{array}$ & Loam & 5 & $3,400,000$ & 130 & 11.8 & 0.0 & 0.0 & 0.1 & 0.8 \\
\hline RV09-07 & Renosterveld & $\begin{array}{l}- \\
34,08574444, \\
21,25053333\end{array}$ & Elytrotrappus rhinocerotis & Sandy & 5.4 & $2,040,000$ & 104 & 19.7 & 0.1 & 0.1 & 0.5 & 0.6 \\
\hline RV09-08 & Renosterveld & $\begin{array}{l}- \\
34,08585833, \\
21,25053056\end{array}$ & $\begin{array}{l}\text { Eragrostis curvula; Elytrotrappus } \\
\text { rhinocerotis }\end{array}$ & Sandy & 5.8 & $2,250,000$ & 193 & 19.4 & 0.0 & 0.0 & 0.3 & 0.7 \\
\hline RV10-01 & Renosterveld & $\begin{array}{l}- \\
34,16553056, \\
22,005425\end{array}$ & Romulea flava & Loam & 6.2 & $3,000,000$ & 201 & 4 & 0.0 & 0.0 & 0.2 & 0.7 \\
\hline RV10-02 & Renosterveld & $\begin{array}{l}- \\
34,03324722, \\
22,30835\end{array}$ & Moraea sp. & Loam & 5.9 & $2,500,000$ & 179 & 2.4 & 0.0 & 0.0 & 0.4 & 0.7 \\
\hline RV10-03 & Renosterveld & $\begin{array}{l}-34,01595 \\
22,00685\end{array}$ & Hypoxis villosa & Loam & 5.8 & $2,740,000$ & 196 & 9.6 & 0.1 & 0.2 & 0.1 & 0.6 \\
\hline RV10-04 & Renosterveld & $\begin{array}{l}- \\
34,10858611, \\
22,04568333\end{array}$ & Ehrharta bulbosa & Loam & 5.6 & $2,990,000$ & 171 & 4.8 & 0.1 & 0.2 & 0.4 & 0.9 \\
\hline RV10-09 & Renosterveld & $\begin{array}{l}- \\
34,28396111, \\
21,76596111\end{array}$ & Elytropappus rhinocerotis & Sand & 5.8 & $1,380,000$ & 177 & 5.8 & 0.1 & 0.1 & 0.8 & 0.5 \\
\hline RV11-04 & Renosterveld & $-\overline{34,28876667,}$ & $\begin{array}{l}\text { Eriocephalus africanus; Elytopappus } \\
\text { rhinocerotis; Ruschia sp. }\end{array}$ & Sand & 5 & $1,480,000$ & 230 & 0.4 & 0.1 & 0.1 & 0.6 & 0.8 \\
\hline
\end{tabular}


21,89245

\begin{tabular}{|c|c|c|c|c|c|c|c|c|c|c|c|c|}
\hline RV11-11 & Renosterveld & $\begin{array}{l}-34,1148 \\
21,25161667\end{array}$ & $\begin{array}{l}\text { Elytropappus rhinocerotis; } \\
\text { Eriocephalus africanus; Themeda } \\
\text { triandra }\end{array}$ & Loam & 5.3 & $4,850,000$ & 220 & 2.4 & 0.1 & 0.2 & 0.2 & 0.9 \\
\hline RV11-15 & Renosterveld & $\begin{array}{l}- \\
34,23876667, \\
21,79173333\end{array}$ & $\begin{array}{l}\text { Elytropappus rhinocerotis; } \\
\text { Restionaceae; Asteraceae }\end{array}$ & Loam & 6.8 & 130,000 & 64 & 0 & 0.4 & 0.5 & 0.6 & 0.7 \\
\hline RV11-22 & Renosterveld & $\begin{array}{l}- \\
34,10561667, \\
21,30705\end{array}$ & $\begin{array}{l}\text { Elytropappus rhinocerotis; Searsia } \\
\text { graveolens; Poaceae }\end{array}$ & Loam & 4.9 & $2,550,000$ & 186 & 0.5 & 0.0 & 0.0 & 0.2 & 0.8 \\
\hline RV11-32 & Renosterveld & $\begin{array}{l}- \\
34,11173333, \\
21,01186667\end{array}$ & $\begin{array}{l}\text { Elytropappus rhinocerotis; Aloe ferox; } \\
\text { Ehrharta villosa; Themeda triandra }\end{array}$ & Sand & 4.8 & $2,260,000$ & 200 & 1.5 & 0.0 & 0.0 & 0.4 & 0.9 \\
\hline RV11-58 & Renosterveld & $\begin{array}{l}-34,29145 \\
21,01003333\end{array}$ & $\begin{array}{l}\text { Roepera morgsana; Euphorbia } \\
\text { mauritanica; Aloe ferox }\end{array}$ & Loam & 6.3 & 620,000 & 187 & 3.3 & 0.1 & 0.1 & 0.5 & 0.7 \\
\hline RV11-67 & Renosterveld & $\begin{array}{l}- \\
34,25323333 \\
20,9884\end{array}$ & $\begin{array}{l}\text { Searsia glauca; Aloe ferox; Euphorbia } \\
\text { mauritanica }\end{array}$ & Loam & 5.2 & $1,200,000$ & 186 & 3.3 & 0.0 & 0.0 & 0.5 & 0.8 \\
\hline \multicolumn{13}{|c|}{ Thicket biome } \\
\hline StT09-04 & Subtropical thicket & $\begin{array}{l}-34,235825 \\
21,91684722\end{array}$ & Sideroxylon inerme & Sandy/loam & 6.1 & 450,000 & 94 & 13.8 & 0.1 & 0.1 & 0.3 & 0.7 \\
\hline StT09-05 & Subtropical thicket & $\begin{array}{l}-34,235825 \\
21,91685\end{array}$ & Eriocephalus africanus & Sand & 7 & 260,000 & 79 & 16.8 & 0.2 & 0.2 & 0.8 & 0.8 \\
\hline StT09-06 & Subtropical thicket & $\begin{array}{l}- \\
34,25073056, \\
21,90236111\end{array}$ & Searsia pterota & Sand & 5.3 & $1,190,000$ & 127 & 15.9 & 0.1 & 0.1 & 0.5 & 0.6 \\
\hline CT06-01 & Coastal thicket & $\begin{array}{l}- \\
34,20847222, \\
22,08953889\end{array}$ & Dense shrubby vegetation & Sand & 8 & 150,000 & 61 & 39 & 0.1 & 0.1 & 0.5 & 0.7 \\
\hline CT06-02 & Coastal thicket & $\begin{array}{l}- \\
34,20847222, \\
22,08953889\end{array}$ & Dense shrubby vegetation & Sand & 8 & 230,000 & 68 & 26.9 & 0.2 & 0.2 & 0.3 & 0.6 \\
\hline CT06-03 & Coastal thicket & $\begin{array}{l}- \\
34,20847222, \\
22,08953889\end{array}$ & Dense shrubby vegetation & Sand & 7.9 & 78,000 & 39 & 46.6 & - & - & - & - \\
\hline CT06-04 & Coastal thicket & $\begin{array}{l}- \\
34,20847222, \\
22,08953889\end{array}$ & Dense shrubby vegetation & Sand & 7.5 & 23,000 & 12 & 29.4 & - & - & - & - \\
\hline CT06-05 & Coastal thicket & $\begin{array}{l}34,20847222, \\
22,08953889\end{array}$ & $\begin{array}{l}\text { Open grassy area of Eragrostis } \\
\text { curvula }\end{array}$ & Sand & 8 & 76,000 & 71 & 5.3 & 0.0 & 0.0 & 1.0 & 0.1 \\
\hline CT06-06 & Coastal thicket & $\begin{array}{l}34,20847222, \\
22,08953889\end{array}$ & Acacia karroo & Sand & 6.6 & 100,000 & 54 & 35.7 & 0.1 & 0.1 & 0.7 & 0.6 \\
\hline СT06-07 & Coastal thicket & - & Dense shrubby vegetation & Loam & 8.3 & 920,000 & 20 & 56.5 & - & - & - & - \\
\hline
\end{tabular}


22,08953889

\begin{tabular}{|c|c|c|c|c|c|c|c|c|c|c|c|c|}
\hline CT10-12 & Coastal thicket & $\begin{array}{l}- \\
34,05521667, \\
22,38678333\end{array}$ & $\begin{array}{l}\text { Eragrostis rehmannii; } \text { Asparagus sp.; } \\
\text { Chasmanthe aethiopica; Rhoicissus } \mathrm{sp} .\end{array}$ & Loam & 6 & 28,000 & 45 & 4.3 & - & - & - & - \\
\hline STV11-01 & Strandveld & $\begin{array}{l}- \\
34,37883333 \\
21,41118333\end{array}$ & $\begin{array}{l}\text { Stoebe cinorera; Erharta villosa. } \\
\text { Restionaceae }\end{array}$ & Sand & 5.3 & 185,000 & 103 & 4.8 & 0.3 & 0.7 & 0.2 & 0.8 \\
\hline STV11-16 & Strandveld & $\begin{array}{l}-34,4132 \\
21,37246667\end{array}$ & $\begin{array}{l}\text { Poaceae; Restionaceae; Sideroxylon } \\
\text { inerme }\end{array}$ & Sand & 5.9 & 513,000 & 122 & 4.5 & 0.1 & 0.2 & 0.8 & 0.7 \\
\hline STV11-20 & Strandveld & $\begin{array}{l}- \\
34,36381667, \\
21,47653333\end{array}$ & Agathosma sp.; Asteraceae & Sand & 7.6 & 20,000 & 24 & 14.3 & - & - & - & - \\
\hline STV11-21 & Strandveld & $\begin{array}{l}-34,3731 \\
21,64463333\end{array}$ & Asteraceae; Poaceae & Sand & 7.4 & 83,000 & 60 & 5 & 0.1 & 0.1 & 0.0 & 0.8 \\
\hline STV11-51 & Strandveld & $\begin{array}{l}- \\
34,37893333, \\
20,85816667\end{array}$ & $\begin{array}{l}\text { Restionaceae; Olea europaea subsp. } \\
\text { Africana; Metalasia sp.; Agathosma } \\
\text { sp. }\end{array}$ & Sand & 7.5 & 75,000 & 48 & 8.3 & - & - & - & - \\
\hline STV11-54 & Strandveld & $\begin{array}{l}-34,40275 \\
21,21333333\end{array}$ & $\begin{array}{l}\text { Metalasia sp.; Searsia graviolens; } \\
\text { Chrysanthemoides monilifera; } \\
\text { Thamnochortus insignis }\end{array}$ & Sand & 7.9 & 7,500 & 11 & 10 & - & - & - & - \\
\hline STV11-55 & Strandveld & $\begin{array}{l}- \\
34,38378333 \\
21,22213333\end{array}$ & $\begin{array}{l}\text { Sideroxylon inerme; Chasmanthe } \\
\text { aethiopica; Searsia glauca; } \\
\text { Thamnochortus insignis }\end{array}$ & Sand & 7.6 & 7,500 & 11 & 22.2 & - & - & - & - \\
\hline DC11-18 & Dune cordon & $\begin{array}{l}- \\
34,41866667, \\
21,35148333\end{array}$ & $\begin{array}{l}\text { Restionaceae; Chrysanthemoides } \\
\text { monilifera; Sideroxylon inerme }\end{array}$ & Sand & 5.6 & 83,000 & 65 & 3.2 & 0.3 & 0.3 & 0.9 & 0.7 \\
\hline DC11-38 & Dune cordon & $\begin{array}{l}- \\
34,39383333 \\
21,41353333\end{array}$ & $\begin{array}{l}\text { Roepera morgsana; Carpobrotus } \\
\text { accinaciformus; Euphorbia } \\
\text { mauritanica }\end{array}$ & Sand & 6.7 & 7,000 & 36 & 8.8 & - & - & - & - \\
\hline DC11-39 & Dune cordon & $\begin{array}{l}-34,43165 \\
21,32283333\end{array}$ & $\begin{array}{l}\text { Osteospernum moniliferum; } \\
\text { Carpobrotus edulis; Roepera } \\
\text { morgsana }\end{array}$ & Sand & 7.4 & 27,000 & 19 & 5.3 & - & - & - & - \\
\hline DC11-71 & Dune cordon & $\begin{array}{l}-34,3667 \\
20,92925\end{array}$ & $\begin{array}{l}\text { Searsia glauca; Phylica ericoides; } \\
\text { Asteraceae }\end{array}$ & Sand & 7.9 & 22,000 & 9 & 11.1 & - & - & - & - \\
\hline DC11-72 & Dune cordon & $\begin{array}{l}- \\
34,36693333 \\
20,92425\end{array}$ & Sideroxylon inerme & Sand & 7.3 & 37,000 & 21 & 0 & - & - & - & - \\
\hline DC11-73 & Dune cordon & $\begin{array}{l}- \\
34,36998333 \\
20,91175\end{array}$ & $\begin{array}{l}\text { Roepera morgsana; Asteraceae; } \\
\text { Carpobrotus edulis }\end{array}$ & Sand & 7.8 & 28,000 & 27 & 0 & - & - & - & - \\
\hline DC11-75 & Dune cordon & $\begin{array}{l}- \\
34,39611667 \\
20,8443\end{array}$ & $\begin{array}{l}\text { Pterocarpus tricuspidatus; Phylica } \\
\text { ericoides }\end{array}$ & Sand & 7.8 & 38,000 & 13 & 0 & - & - & - & - \\
\hline \multicolumn{13}{|c|}{ Forest biome } \\
\hline CF10-13 & Coastal Forest & $\begin{array}{l}-34,06155 \\
23,03056667\end{array}$ & Celtis sp.; Vepris sp. & Loam & 6 & 345,000 & 108 & 2.7 & 0.0 & 0.0 & 0.2 & 0.3 \\
\hline
\end{tabular}




\begin{tabular}{|c|c|c|c|c|c|c|c|c|c|c|c|c|}
\hline \multicolumn{13}{|l|}{ Azonal } \\
\hline RP11-13 & Riparian & $\begin{array}{l}- \\
34,25971667, \\
21,78031667\end{array}$ & Acacia karroo; Poaceae; Asteraceae & Sand & 5.5 & $2,440,000$ & 166 & 0.6 & 0.0 & 0.0 & 0.7 & 0.5 \\
\hline RP11-14 & Riparian & $\begin{array}{l}34,26373333, \\
21,77966667\end{array}$ & Acacia karroo; Poaceae; Asteraceae & Sand & 6.2 & $1,240,000$ & 203 & 3 & 0.0 & 0.0 & 0.8 & 0.4 \\
\hline RP11-48 & Riparian & $\begin{array}{l}- \\
34,33896667, \\
21,02705\end{array}$ & $\begin{array}{l}\text { Euphorbia mauritanica; Roepera } \\
\text { morgsana }\end{array}$ & Sand & 7.3 & 97,000 & 55 & 3.8 & 0.1 & 0.1 & 0.8 & 0.5 \\
\hline RP11-49 & Riparian & $\begin{array}{l}- \\
34,32151667, \\
20,77593333\end{array}$ & Acacia karroo; Poaceae & Loam & 6.9 & $4,300,000$ & 220 & 2.7 & 0.0 & 0.0 & 0.3 & 0.6 \\
\hline RP11-59 & Riparian & $\begin{array}{l}34,30161667, \\
21,01116667\end{array}$ & Acacia karroo; Poaceae & Sand & 7.3 & 850,000 & 156 & 1.9 & 0.0 & 0.0 & 0.8 & 0.7 \\
\hline RP11-79 & Riparian & $\begin{array}{l}- \\
34,04986667, \\
21,75665\end{array}$ & $\begin{array}{l}\text { Acacia karroo; Albuca maxima; } \\
\text { Poaceae; Aloe ferox }\end{array}$ & Sand & 4.7 & $1,170,000$ & 193 & 3.1 & 0.0 & 0.0 & 0.7 & 0.5 \\
\hline RP11-80 & Riparian & $\begin{array}{l}- \\
34,08223333, \\
21,77531667\end{array}$ & Acacia karroo; Albuca maxima & Sand & 5.4 & 340,000 & 64 & 0 & 0.0 & 0.0 & 0.8 & 0.5 \\
\hline W10-08 & Wetland & $\begin{array}{l}-34,0608 \\
22,10786667\end{array}$ & $\begin{array}{l}\text { Cyperus textilis; Stenotaphrum } \\
\text { secundatum; Arundo sp. }\end{array}$ & Loam & 6 & $1,590,000$ & 183 & 7.6 & 0.1 & 0.1 & 0.2 & 0.7 \\
\hline
\end{tabular}

